\title{
Fungicides for Wood Protection - World Viewpoint and Evaluation/Testing in Slovakia
}

\author{
Ladislav Reinprecht \\ Faculty of Wood Sciences and Technology, Technical University of Zvolen \\ T. G. Masaryka 24, SK-960 53 Zvolen, \\ Slovakia
}

\section{Introduction}

Hardwoods (e.g. ash, beech, oak, poplar) and softwoods (e.g. fir, pine, spruce) consist of various types of cells: vessel elements, tracheids, libriform fibres, axial parenchyma cells, ray parenchyma cells, epithelial cells, etc. These cells exhibit various orientations in relation to the standing tree and provide various functions, such as, imparting mechanical strength, acting as water-conducting elements, or functioning as storage cells. Wood cells, their cell walls and lumens have typical shapes and dimensions. Cell walls usually consist of primary and secondary wall layers which are made up from basic natural polymers: cellulose, hemicelluloses and lignin. Extractives of durable wood species (such as terpenoids, tropolones, stilbenes, flavonoids or chinones) are usually present in the cell lumens, or sometimes even in the cell walls (Fengel \& Wegener 1984).

Wood is a natural organic material and as such it can be degraded by biological agents: bacteria, fungi and insects. The use of wood is thereby limited by its susceptibility to organisms that may damage its structure and deteriorate its properties.

Wood-destroying fungi, such as brown-rot (Serpula lacrymans, Coniophora puteana, Antrodia vaillantii, Gloeophyllum trabeum, Lentinus lepideus, etc.) and white-rot (Trametes versicolor, Trametes hirsuta, Schizophyllum commune, etc.) basidiomycetes, or soft-rot (Chaetomium globosum, Monodictys putredinis, etc.) ascomycetes, destroy polysaccharides (cellulose and hemicelluloses) present in the cell walls. They may also, in different degrees, degrade the lignin (Arantes et al. 2010, Schmidt 2006). Fungi attain the depolymerization of polysaccharides by producing various types of hydrolytic enzymes, e.g. degradation of crystalline cellulose is achieved using etracellular endo-1,4- $\$$-glucanases, exo-1,4- $\$$ glucanases, and 1,4-\$-glucosidase. Brown rot-fungi - which do not have exo-1,4-\$glucanases - use the low molecular non-enzymatic Fenton chelator-mediated system consisting of oxalic acid, iron cations and hydrogen peroxide (Eriksson et al. 1990, Goodell et al. 2007, Hastrup et al. 2010, Messner et al. 2003). Rotten wood has lower density and lower strength (Reinprecht 1992, Wilcox 1978). In parallel to the changes above, rot-fungi also change the moisture, colour, acoustic and other properties of wood, with an expressive influence on wood quality. However, these fungi can only degrade the structural components of wood in situations when its moisture content (MC) is $20 \%$ or more (Carll \& Highley 1999). 
Other wood-degrading fungi, such as blue stain fungi (commonly called staining fungi growing inside of wood) and microscopic fungi (commonly called moulds - growing on wood surfaces), are not able to depolymerise the cellulose and other building polymers in the cell walls of wood. These fungi metabolize simple sugars and starch present in ray cells and axial cell lumens. Staining fungi (Ceratocystis pilifera, Aureobasidium pullulans, Alternaria alternata, etc.) release pigments and cause colour changes in inner parts of the wood, while simultaneously increasing its permeability as a result of fine perforation of cell walls by penetration hyphae and also by disruption of pits in tracheids or in other cell elements. Some of these strains are also known to be able to cause soft rot in hardwoods under optimal conditions (e.g. Phialophora spp.). Colonization of wood by staining fungi occurs at moisture contents (MC) above $30 \%$, e.g. sapwood of softwoods is optimally attacked at MC of $100-130$ $\%$, while sapwood of tropical and other hardwoods at MC of $40-80 \%$ (Fougerousse 1985, Zabel \& Morrell 1992). Moulds (Aspergillus niger, Penicillium brevi-compactum, Trichoderma viride, etc.) produce masses of coloured spores on wood surfaces, and some of them also yield pigments (Reinprecht 2008). Moulds have only a minor influence on wood quality. Growth of moulds on wood surfaces is not so dominantly dependant on the wood's MC, as they are influenced mainly by the relative humidity (RH) of the surrounding air, which has to be minimally about $80 \%$ (Viitanen \& Ritschkoff 1991).

Protection of solid wood and wooden materials (plywood, laminated veneer lumbers, particleboards, fibreboards, etc.) prior to fungal attacks can be accomplished by the use of one of the following procedures:

- $\quad$ exposure of wood and wooden products to convenient environmental conditions, e.g. without contact with ground and without influence of rain using various design tools (Foliente et al. 2002), when MC of wood is stable under $20-26 \%$ and RH of air is stable under 80 - $90 \%$ (Wang \& Morris 2010),

- $\quad$ usage of more durable wood species (EN 350-2, Taylor et al. 2002, Van Acker et al. 2003),

- thermal, chemical or enzymatic modification of wood (Hill 2006, Reinprecht \& Vidholdová 2008),

- bio-control of wood with antagonist organisms (Phillips-Laing et al. 2003, Singh \& Chittenden 2008),

- application of fungicides.

In the present, the service life of wooden products exposed to wet conditions is usually increased by using more durable wood species or by treatment of wood with effective and ecologically convenient fungicides (Brischke \& Rapp 2008). However, in the future a bigger emphasis will be given to the use of modified woods, without any negative influence on the environment (Suttie 2008).

Sleepers, poles, fences, shingles, decking, cladding, windows, log cabins, and many other wooden products exposed to exterior commonly have an MC above $20 \%$. The requirement of their fungicide protection in the $2^{\text {nd }}$ till $5^{\text {th }}$ classes of exposure by the EN 335-1 depends on the natural durability of used wood species by the EN 350-2. For wooden structural elements it is complexly given in the EN 460. Wood species with a lower amount of decayinhibiting heartwood extractives (terpenoids, stilbenes, etc.) have a minimal natural durability, e.g. beech, birch, hornbeam, poplar, fir, spruce, and more others (EN 350-2). In this fact, wooden products from less durable wood species intended for higher risk inservice expositions have to be made either from modified wood substances (e.g. plywood from thermally modified or acetylated veneers), or from wood substance, glue or paint treated with a suitable fungicide (see Chapter 2). 


\section{Fungicides used for wood protection - world viewpoint}

Fungicides are inorganic or organic substances acting against fungi (Tab. 1). Their toxicant or retardant mode of action depends on their chemical structure from which all important biocidal properties are derived. Some fungicides have simultaneously bactericidal, insecticidal or other biocidal effects, e.g. boric acid (Lloyd 1998).

\subsection{Modes of action of fungicides and their efficacy}

Activity of the wood-degrading fungi can be suppressed by more biochemical modes of action of fungicides (Eaton \& Hale 1993, Reinprecht 2008):

- Inhibitors of respiration, by which either the formation of acetyl coenzyme A (CoA) is inhibited or the respiratory chain phosphorylation is interrupted, and simultaneously production of the high-energy intermediate "adenosine triphosphate" (ATP) is suppressed. Cupric ion $\mathrm{Cu}^{2+}$ from copper sulphate, copper oxide, copper naphthenate, copper-8-hydroxyquinolinate, $\mathrm{Cu}-\mathrm{HDO}$, etc. is a typical inhibitor of respiration processes in fungal cells. It has affinity to different chemical groups in the cells of fungi, particularly to thiol groups, resulting in the non-specific denaturation of proteins and enzymes. Similar inhibitory effects were found at the arsenic compounds, 2phenylphenol, pentachlorophenol and other phenolic compounds, carboxamides, tributyltin compounds, or isothiazolones.

- Inhibitors of polysaccharide biosynthesis, and/or inhibitors of protein, lipid and nucleic acid biosynthesis. Well known inhibitors of the chitin (polysaccharide from Nacetylglucosamine units) synthesis in the cell walls of fungi are polyoxins, antibiotics derived from a streptomycete. Lipid synthesis is suppressed by imidazoles, pyrimidines, or triazoles.

- Inhibitors of cell division act by inhibiting the synthesis of microtubules. During cell division (mitosis) the genetic information stored in the nucleus in DNA (deoxyribonucleic acid) must be copied and the products transformed to the two daughter cells. The benzimidazole derivatives (e.g. carbendazim, benomyl) interfere with microtubule subunit polymerization and such preventing mitosis, at which depress the DNA synthesis, as well.

- Disruptors of cell membranes of fungi, in which structure and function the sterols (especially ergosterol) play an important role. Tiazoles (e.g. azaconazole, propiconazole, tebuconazole) act as inhibitors of sterol biosynthesis, and this process is connected with disruption of cell membranes. Tar oils also disrupt the cell membranes when the lipids in membranes are soluble in the non-polar oil liquids. Semi-permeable membranes of fungi can be dehydrated and damaged by quarternary ammonium compounds (QAC), e.g. by didecyl-dimetyl-ammonium chloride (DDAC), in connection with leaking of cell constituents.

- In-activators of enzymes usually inhibit several enzymatic processes at the same time. They often react with thiol groups in proteins (e.g. mercury-based fungicides used in the past, dicarboximides), inhibit glycolysis (e.g. mercury $\mathrm{Hg}^{2+}$ and copper $\mathrm{Cu}^{2+}$ cations), or inhibit other enzymatic reactions (e.g. boric acid and various boron compounds which form stable complexes with vitamins, coenzymes or other biological molecules having e.g. poly-ols groups (Lloyd et al. 1990), and simultaneously inhibit metabolic activity, enzymatic function and growth of fungi - so they act more as fungistatics rather than fungicides). 
- Retardants of Fenton depolymerisation of polysaccharides in cells of wood are substances which chemically bond $\mathrm{Fe}^{3+}$ ions (e.g. tropolon, $\beta$-tujaplicin), and in this fact decrease the activity of brown-rot fungi (Gérardin et al. 2002).

- Retardants of fungal spread in wood and other materials in buildings, e.g. non-toxic amino acid analogue "AIB" $\alpha$-aminoisobutyric acid targets adaptive nitrogen redistribution mechanisms that are unique to rot-fungi, and which are essential to their ability to spread in buildings and colonise fresh wood sources poor in nitrogen (Watkinson \& Tlalka 2008).

Efficacy of fungicides depends on their ability to damage fungal cells, suppress growth, enzymatic or other activities of rotting-fungi in wooden or in model testing substrates, etc. In laboratory and field tests, and also in practice it is determined as a critical minimal concentration (\%) or as a minimal critical retention in wood $\left(\mathrm{g} / \mathrm{m}^{2}, \mathrm{~kg} / \mathrm{m}^{3}\right)$. However, efficacy is not a constant value, because it is influenced by more biological and environmental factors presented inside and outside of the fungal cells (Reinprecht 2008):

- velocity of adsorption of fungicide on the surface of fungal cells, which depends e.g. on the $\mathrm{pH}$ value of wood,

- velocity of accumulation of fungicide into fungal cells, which can be increased in presence of conditioners,

- species of fungus, when individual fungi non-seldom have a selective resistance to the molecule of fungicide (e.g. borates are effective against rotting-fungi but not against moulds; copper compounds are effective against soft-rot fungi, staining fungi and moulds but they have a lower efficacy against white-rot and brown-rot fungi, especially against fungi from the families of Antrodia and Serpula which create non-toxic crystals of copper oxalate (Hastrup et al. 2005),

- amount of fungal cells, because the fungicide in interaction with cells of a living fungus can be sometimes inactivated and its concentration is brought down (e.g. fungicide for curative usage have to be applied in a higher concentration than for preventive usage),

- amount of the applied fungicide, because its under-critical concentrations are not usually effective for a long time, when the fungus can be adapted on molecules of the fungicide, presence of other substances, which catalyse or retard efficacy of the fungicide (e.g. efficacy of QAC is synergistically increased in presence of inorganic copper compounds (Härtner \& Barth 1996)),

- temperature, moisture, UV light and other environmental factors, which influence the activity of fungal cells (e.g. cells are disposed to damage at higher temperatures - so the necessary of fungicide molecules is lower), the transport of fungicide to fungal cells (e.g. diffusion transport of water soluble fungicides is more intensive in wetter and warmer wood substance - so the necessary of fungicide molecules is lower), etc.

\subsection{The most used fungicides for wood protection}

Natural decay resistance of wood, plywood and other wooden materials against fungi can be increased by various synthetic and natural chemicals having fungicide or fungistatic effects.

In the $20^{\text {th }}$ century, protection of wood against fungi included the use of the following chemicals: traditional coal tar oils, various mercury-based compounds $\left(\mathrm{HgCl}_{2}, \ldots\right)$, fluorine compounds (NaF, KF, CuSiF $6.6 \mathrm{H}_{2} \mathrm{O}, \mathrm{MgSiF}_{6} .6 \mathrm{H}_{2} \mathrm{O}, \mathrm{ZnSiF}_{6} .6 \mathrm{H}_{2} \mathrm{O}, \mathrm{Na}_{2} \mathrm{SiF}_{6} .6 \mathrm{H}_{2} \mathrm{O}, \ldots$ ), arsenicbased compounds $\left(\mathrm{As}_{2} \mathrm{O}_{3}, \mathrm{As}_{2} \mathrm{O}_{5}, \mathrm{FeAsS}, \mathrm{Na}_{2} \mathrm{HAsO}_{4}, \ldots\right)$, copper-based compounds $\left(\mathrm{CuSO}_{4} \cdot 5 \mathrm{H}_{2} \mathrm{O}, \quad \mathrm{CuO}, \quad \mathrm{CuCO}_{3} \cdot \mathrm{Cu}(\mathrm{OH})_{2}, \quad \mathrm{Cu}-\mathrm{HDO}=\mathrm{bis} / \mathrm{N}-\right.$ 
cyclohexyldiazeniumdioxy/copper, $\mathrm{CuN}=$ copper naphthenates, copper-8-quinolinolate, ...), zinc-based compounds $\left(\mathrm{ZnCl}_{2}, \mathrm{ZnO}, \ldots\right)$, chromium-compounds $\left(\mathrm{Na}_{2} \mathrm{Cr}_{2} \mathrm{O}_{7}, \mathrm{~K}_{2} \mathrm{Cr}_{2} \mathrm{O}_{7}\right.$, $\left.\mathrm{CrO}_{3}, \ldots\right)$, boron compounds $\left(\mathrm{H}_{3} \mathrm{BO}_{3}, \mathrm{Na}_{2} \mathrm{~B}_{4} \mathrm{O}_{7} .10 \mathrm{H}_{2} \mathrm{O}, \ldots\right)$, quarternary alkyl-ammonium compounds (QAC, e.g. DDAC = didecyl-dimetyl-ammonium chloride), pentachlorophenol (PCP) and its sodium salt sodium pentachlorophenolate, organotin compounds (TBTO = bis/tributyltin/oxide, ...), etc. In the $70-90^{\text {th }}$ years of the $20^{\text {th }}$ century new organic substances have been tested and subsequently used for protection of wooden structures against fungi, e.g. sulfamides (dichlofluanid, tolylfluanid, ...), carbamates (IPBC $=3$-iodo-2-propynylbutyl-carbamate), dithiocarbamates, but first of all various hetero-cycles - e.g. benzothiazoles (TCMTB = 2-thiocynomethylthio-benzothiazole, ...), benzoimidazoles (carbendazim, thiabendazole $=$ 2-thiazol-4-yl-1H-benzoimidazole, ...), triazoles (propiconazole, tebuconazole, ...), isothiazolones (DCOIT $=4,5$-dichloro-2-n-octyl-4isothiazol-3-one), or furan derivatives with the biologically active group $\mathrm{CH}_{3}-\mathrm{C}=\mathrm{C}-\mathrm{C}=\mathrm{O}$ (furmecyclox, ...) (Eaton \& Hale 1993, Reinprecht 1996, 2008, Richardson 1993, Unger et al. 2001).

Fungicides containing the fluorine, arsenic, copper or zinc molecules with predestination for exterior expositions were usually combined with chromium, which fixed them into stable in water non-soluble complexes, e.g. $\mathrm{F} / \mathrm{Cr}=$ Wolmanit $\mathrm{U}, \mathrm{Cu} / \mathrm{Cr}=\mathrm{CC}$ salts, $\mathrm{Cu} / \mathrm{Cr} / \mathrm{B}=\mathrm{CCB}$ salts, $\mathrm{Cu} / \mathrm{Zn} / \mathrm{Cr} / \mathrm{B}=\mathrm{CBZ}$ salts, $\mathrm{Cu} / \mathrm{Cr} / \mathrm{As}=\mathrm{CCA}$ salts, etc. (Dahlgren \& Hartford 1972, Peek \& Willeitner 1984). In present years the chromium can be, by the Biocidal Product Directive 98/8/EC, used only as a fixative agent in the form of chromic acid $\mathrm{CrO}_{3}$, not as a fungicide (Jüngel \& Melcher 2006, Jüngel \& Hellkamp 2008). Applications of the mercury, fluorine, pentachlorophenol, organotin and also of some other compounds including traditional compositions of tar oils with the carcinogen benzo- $\alpha$-pyrene, have been stopped already during the $20^{\text {th }}$ century due to environmental, health or other aspects.

Today in the $21^{\text {st }}$ century, the industrial protection of wood against fungi has responded to environmental, legislative and economic pressures to utilize more environmentally sensitive formulations (Wallace \& Dickinson 2006). Usage of arsenic in the copper-chromatedarsenate (CCA) and in other preservatives was restricted (Preston 2000, Evans 2003). Timber preservation is carried out either with modified coal tar oils "creosotes" without benzo- $\alpha$ pyrene and having only a minimal amount of easily evaporated naphtalene derivatives (tar oils only for pressure impregnation of sleepers and poles), and with selected types of inorganic and organic fungicides having oral $\mathrm{LD}_{50}$ above $500 \mathrm{ppm}$ for the animal organisms, at which these fungicides may not have mutagenic and cancer effects on animals (Tab. 1).

Coming out from the health and environmental demands on biocidal products determined in the Directive 98/8/EC of the European Parliament and of the Council of 16 February 1998, and also in its other Commission Regulation (EC) reports No. 1896/2000, 2032/2003, 1048/2005, 1849/2006 1451/2007, only a limited number of active substances will be permitted in the European market after 2014 (Krajewski \& Strzelczyk-Urbaňska 2009). Already today in the Annex I to the Directive 98/8/EC there is only a small number of active substances from PT 8 (wood preservatives), e.g. fungicides IPBC, K-HDO, propiconazole, tebuconazole, dichlofluanid, or thiabendazole.

As a result of these regulations, in the future will probably be a reduced interest for investigation of new biocidal - fungicide active substances, mainly those on the basis of heavy metals (not only chromium, tin or arsenic, but also copper, etc.), which usage is already now limited in a practice. According to Leithoff \& Blancquaert (2006) the price for notification of existing active substances varies from 3.3 to 6.0 million Euro, at which the 


\begin{tabular}{|c|c|c|c|}
\hline & \multirow[t]{2}{*}{ BIOCIDE } & \multicolumn{2}{|c|}{ EFFICACY } \\
\hline & & Fungicide & Insecticide \\
\hline$\square$ & Boron compounds (boric acid, borax, ...) & + & + \\
\hline$\square$ & Carbamates $(\mathrm{IPBC}, \ldots)$ & + & \\
\hline$\square$ & Copper inorganic compounds (copper oxide, ...) & + & \\
\hline$\square$ & Copper naphtenates and citrates & + & \\
\hline$\square$ & Creosotes & + & + \\
\hline$\square$ & Isotiazolones (DCOIT, ...) & + & \\
\hline$\square$ & N-organodiazeniumdioxy-metals (Cu-HDO, ...) & + & $(+)$ \\
\hline$\square$ & Quarternary ammonium compounds - QAC (DDAC, ...) & + & $(+)$ \\
\hline$\square$ & Sulfamides (dichlofluanid, tolylfluanid, ...) & + & \\
\hline$\square$ & Triazoles (propiconazole, tebuconazole, ...) & + & \\
\hline$\square$ & Natural substances (chitosan, essential oils, ...) & + & $(+)$ \\
\hline
\end{tabular}

Note: + it is a basic biocidal activity; (+) it is an additional biocidal activity

Table 1. The most important fungicides for wood protection used today in the Europe and also in the world (Reinprecht \& Tiralová 2007a)

highest $85-90 \%$ expenses are connected with the toxicology and eco-toxicology studies. Lower prices are needed for registration of existing (0.2-0.5 million Euro) or new preservative products (0.3-1.4 million Euro). On the other hand, the price for evaluation, notification and registration of a new active substance is usually from 30 to 40 million Euro (Reinprecht 2008).

Commercial wood preservatives used in the present contain mainly boron compounds (boric acid, disodium tetraborate, disodium octaborate, glycol borates, etc. often modified with fixatives, water repellents or other protective additives against leaching), quarternary alkyl-ammonium compounds, triazoles (azaconazole, propiconazole, tebuconazole), benzoimidazoles, isothiazolones, sulfamides, carboxamides, or 3-iodo-2-propynyl-butylcarbamate, and to this time also various copper-based compounds $\left(\mathrm{CuO}, \mathrm{CuCO}_{3} . \mathrm{Cu} / \mathrm{OH} / 2\right.$, $\mathrm{Cu}-\mathrm{HDO}=$ bis/N-cyclohexyldiazeniumdioxy/copper, etc.). Interesting for the future could be also other compounds with biological efficiency, e.g. aqueous based silver compositions or nano-silver particles - especially those between 100-200 nm (Ellis et al. 2007), triazines (Milata et al. in press), aminosilicone macro emulsions - ASMaE (Ghosh et al. 2008), 1,3dimethylol-4,5-dihydroxy-ethyl-urea - DMDHEU (Xie et al. 2005), or from natural substances especially the chitosan (Schmidt et al. 1995, Eikenes et al. 2005).

Nanotechnologies are surely promising for wood preservation, as well. Nanometal characteristics may be totally different from the characteristics of the elemental metals and potentially may perform in an unusual manner. Nanometal preparations have several characteristics (e.g. size and charge), that may improve their performance in wood protection applications. If their particle size is smaller than the diameter of pores in the bordered pits or in the wood cells, complete penetration and uniform distribution in wood can be expected (Akhtari \& Arefkhani 2010). However, in solid wood with a small amount of trace elements $(\mathrm{Mn}, \mathrm{Fe}, \mathrm{Co}, \mathrm{Ni}, \mathrm{Cu}, \mathrm{Zn}, \mathrm{Mo}, \mathrm{Pb}$, etc), which have a positive or negative physiological influence on the mycelium growth of fungi, the additional treatment of wood tissue with nano-particles of silver, copper, zinc, aluminium or other metals (nanobiocides) can be effective only if their concentration will be under-threshold toxicity range (Wažny \& Kundzewicz 2008). 
From the point of view of efficacy and ecology of fungicides it is also very important their stability in treated wood. The main problem associated with the development of environmentally friendly wood preservatives for high hazard end uses, based on organic compounds, is the observed biotransformation of these chemicals. Some strains of proteobacteria (Alcaligenes, Enterobacter, Pseudomonas, Ralstonia, etc.) are able to degrade IPBC, propiconazole, chlorothalonil and other organic fungicides (Wallace \& Dickinson 2006). Propiconazole and tebuconazole are partly degradable also by the black-stain fungus Epicoccum purpurascens (Stirling \& Morris 2010). According to these authors, if it proves to be possible to disrupt the mechanism of detoxification processes of organic fungicides, this could herald a new generation of environmentally friendly wood preservatives. On the other hand, intentional detoxification of organic fungicides can be important at reconstruction of old heritage buildings, and at remediation of carbon-based preservativetreated wood at the end of its service life.

Boron compounds: Boric acid $\mathrm{H}_{3} \mathrm{BO}_{3}$, disodium-tetraborate-decahydrate $\mathrm{Na}_{2} \mathrm{~B}_{4} \mathrm{O}_{7} .10 \quad \mathrm{H}_{2} \mathrm{O}$ (borax), disodium-octaborate-tetrahydrate $\mathrm{Na}_{2} \mathrm{~B}_{8} \mathrm{O}_{13} .4 \mathrm{H}_{2} \mathrm{O}$ (timbor), zinc borates $\mathrm{Zn}\left(\mathrm{BO}_{2}\right)_{2}$ (Kirkpatrick \& Barnes 2006, Lin \& Furuno 2001), and also some other boron compounds belong to traditional preservatives for wood protection against wood-destroying fungi and insects in interior exposures (Dickinson \& Murphy 1989, Lloyd 1998, Luo et al. 2005). Boron compounds have also certain fire retardant effect. They are usually applied in water solutions, or by diffusion methods at treatment of wet wood. Advantage of these compounds is their low toxicity to humans and the environment. In order to reach a better efficacy, they have to be applied in higher amounts, approximately from 3 to $20 \mathrm{~kg} / \mathrm{m}^{3}$ of wood (Lyon et al. 2009, Pallaske 2004, Reinprecht 2007). Their disadvantage is a lower efficacy against moulds (Reinprecht et al. 1986).

Inorganic boron compounds used in outdoor exposures have to be modified with fixatives or with water repellents, polymerizable monomers or other protective additives to reduce their leachability (Babuder et al. 2004, Lloyd et al. 2001). Polyvinyl alcohols belong to the most known fixatives which form stable complex with the borate ions (Mohareb et al. 2010a). Complexes with boron create also tannins (Pizzi \& Baecker 1996). Fixation of boron in wood can be secured also by silicone gels (Furuno \& Imamura 1998) and animal proteins (Mazela et al. 2007, Thevenon \& Pizzi 2003).

Organic compounds of boron, e.g. in esters (tetramethyl-ammonium bis/salicyl/borates Humphrey et al. 2002; ammonium borate oleate "ABO" - Lyon et al. 2009), are usually more stable against leaching with water. The newly developed didecyl-dimethyl-ammonium tetrafluoroborate (DBF) is acceptably stable as well as effective against white-rot and brownrot basidiomycetes (Kartal et al. 2005) and in soil-bed tests against soft-rot fungi (Kartal et al. 2006). The DBF with or without incorporation with acryl-silicon type resin emulsion showed a good decay resistance against basidiomycetes after severe weathering (Kartal et al. 2004, 2006).

Carbamates: 3-iodo-2-propynyl-butyl-carbamate (IPBC) is an organic fungicide, which can be applied in organic solvents (acetone, xylene), and also in water emulsions. The IPBC is effective against various types of wood-degrading fungi (Hansen 1984), however it is mainly used against moulds and staining fungi. Activity of IPBC against fungi can be enhanced with borates (Cassens \& Eslyn 1981), or against the dry rot fungus Serpula lacrymans approximately about $50 \%$ in the presence of $2 \mathrm{~g} / 1$ of $\alpha$-aminoisobutyric acid (Bota et al. 2010). 


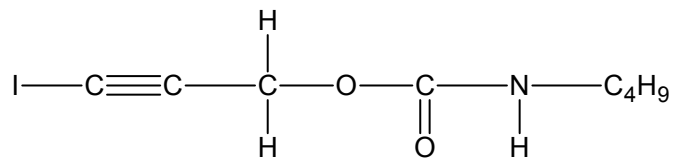

IPBC

Copper compounds: Copper is effective against fungi either in various inorganic compounds: $\mathrm{CuSO}_{4} \cdot 5 \mathrm{H}_{2} \mathrm{O}, \mathrm{CuO}, \mathrm{Cu}(\mathrm{OH})_{2} \cdot \mathrm{CuCO}_{3}, \mathrm{Cu} / \mathrm{Cr} / \mathrm{B}=\mathrm{CCB}$ salts, $\mathrm{Cu} / \mathrm{Cr} / \mathrm{As}=\mathrm{CCA}$ salts, Ammonia $/ \mathrm{Cu} / \mathrm{As}=\mathrm{ACA}$ salts; or in various organic compounds: $\mathrm{CuN}=$ copper naphthenates, copper-8-quinolinolate, $\mathrm{Cu}-\mathrm{HDO}=$ bis/N-cyclohexyldiazeniumdioxy/copper, ACC = ammoniacal copper carboxylates with the structure of R-COO-Cu-OOC-R, e.g. ammoniacal copper citrates, ACQ = alkaline copper quat formulations /e.g. consisted from $\mathrm{CuO}$ and DDAC/ (Eaton \& Hale 1993, Pankras et al. 2009). Copper in the form of $\mathrm{Cu}^{2+}$ cations is especially effective against soft-rot fungi (Ray et al. 2010).

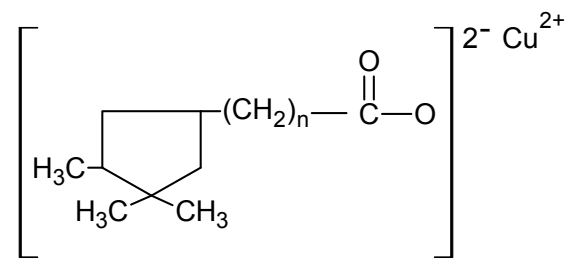

$\mathrm{CuN}$

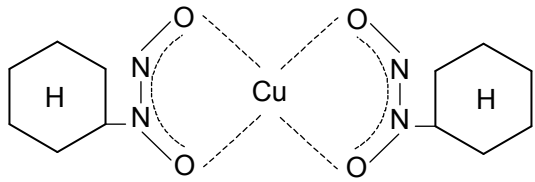

$\mathrm{Cu}-\mathrm{HDO}$

Copper compounds are mainly used in water, amine or organic solutions, but in recent years also in the form of micronized copper particles "MCQ", usually ranging from 10 to 700 $\mathrm{nm}$ (Matsunaga et al. 2007, McIntyre 2010). For example copper carbonate used in the form of MCQ is fixed to wood creating octahedral complexes with six oxygen atoms surrounding the central copper (Xue et al. 2010). From studies made by Chen (2010), it is evident that both oxidation of hemiacetals by $\mathrm{Cu}^{2+}$ in cellulose and hemicelluloses, and oxidation of guaiacyl lignin by $\mathrm{Cu}^{2+}$ to quinone methides took place, which led to complex formation of copper with all wood components. However, for long term efficacy of copper compounds in exterior exposures it is important not only the fixation of copper ions to polysaccharide and lignin in cell walls of wood, but also of their possible migration in the wood, e.g. from the surface of treated wood onto untreated check surfaces (Choi et al. 2001).

However, copper preservatives are not effective against all types of wood-inhabiting fungi. It is well known, that most brown-rot fungi (Serpula lacrymans, Serpula himantioides, Antrodia radiculosa, Oligoporus placentus, Fomitopsis palustris, etc.), which use Fenton reaction at depolymerization of cellulose, are tolerant towards copper-based wood preservatives as a consequence of creation the non-active copper oxalate crystals, as well as other gene predictions (Hastrup et al. 2005, Tang et al. 2010, Schilling \& Inda 2010, Woo \& Morris 2010). Copper oxalate is insoluble in water and copper in this form has a greatly reduced inhibitory effect on fungal growth (Humar et al. 2001). Thereby, broad-spectral preservatives require the addition of suitable co-fungicide (e.g. boron-compound), to protect wood against copper tolerant fungi.

Creosotes: Coal tar oils - creosotes, patented in 1836 by German chemist Franz Moll and first used for wood impregnation by John Bethell in 1838. In the 19th and 20th centuries, creosotes were the most commonly used wood preservatives throughout the world, with a worldwide 
production of approximately 16 million metric tons (Eaton \& Hale 1993). Creosotes consist from 200 to 800 different compounds, mainly from neutral polycyclic aromatic hydrocarbons (anthracene, phenantrene, pyrene, chrysene, ...), tar phenols (cresol, naphtol, ...) and tar bases (quinoline, acridine, ...). They have good fungicide and insecticide effects at wood retention level between $30 \mathrm{~kg} / \mathrm{m}^{3}$ (against insects) and $120 \mathrm{~kg} / \mathrm{m}^{3}$ (against soft-rot fungi). In Europe, their composition and usage is controlled by the West European Institute for Wood Impregnation (WEI). However, now and mainly in the future, their application will be significantly restricted because of their negative influences on the environment.

Isotiazolones: DCOIT (4,5-dichloro-2-n-octyl-4-isothiazol-3-one), Kathone (2-n-octyl-4isothiazol-3-one), Kathone CG (5-chloro-2-methyl-4-isothiazol-3-one) and others isotiazolones are used for wood protection as bactericides and fungicides in retentions from 0.15 to $1.28 \mathrm{~kg} / \mathrm{m}^{3}$. Some of them can also be used against termites. They are applied either in organic solvents or in water emulsions (Hegarty et al. 1997).<smiles>[B]n1sc(Cl)c(Cl)c1=O</smiles>

DCOIT

Quarternary ammonium compounds: QAC with various alkyl or aryl groups $\left(R_{1}, R_{2}, R_{3}, R_{4}\right)$, and with chloride, tetrafluoroborate, nitrate, acetate or other anion X- (Zabielska-Matejuk \& Skrzypczak 2006), have been used approximately 30 years for wood protection (Nicholas \& Preston 1980). QAC are usually more effective against staining fungi and moulds (MicalesGlaeser et al. 2004), and less effective against wood-destroying fungi. However, DDAC (didecyl-dimetyl-ammonium chloride) has a sufficient efficiency against rotting-fungi, as well. QAC are soluble in water and miscible with alcohol. In wood are fixed by ionic reactions with carbonyl groups of lignin and hemicelluloses, and by interactions with its $\mathrm{OH}$ groups (Nicholas et al. 1991). Due to their lower stability in environment, their rapid fixation close to the wood surface, and their influence on higher absorption of water by wood from environment, the QAC are not convenient for treatment of wood in contact with ground. Nowadays, QAC are used for treatments of structural timbers in interior and exterior above ground expositions, usually in combination with copper-compounds (e.g. $\mathrm{CuCO}_{3} \cdot \mathrm{Cu} / \mathrm{OH} / 2$ ), boron-compounds (e.g. $\mathrm{H}_{3} \mathrm{BO}_{3}$ ) or triazoles (e.g. propiconazole) (Reinprecht \& Tiralová 2007a, 2007b).<smiles>[Y][C@H]1CC[R]([R1])([R])N1[R]</smiles>

$\mathrm{R}_{1}, \mathrm{R}_{2}$ - alkyl groups with 1 to 6 carbon atoms

$\mathrm{R}_{3} \quad$ - alkyl group with 1 to 20 carbon atoms, or benzyl group

$\mathrm{R}_{4} \quad$ - alkyl group with 8 to 22 carbon atoms 
Sulfamides: These compounds (dichlofluanid $=\mathrm{N}, \mathrm{N}$-dimethyl- $\mathrm{N}^{\prime}$-phenyl- $\mathrm{N}^{\prime}$ /flurodichloromethylthio/-sulfamide, tolylfluanid $=\mathrm{N}, \mathrm{N}$-dimethyl-N'-p-tolyl-N'/fluorodichloromethylthio/-sulfamide, etc.) have typical active biological groups -S-C$\left(\mathrm{Cl}_{2}\right) \mathrm{F}$ or $-\mathrm{S}-\mathrm{C}-\left(\mathrm{Cl}_{3}\right)$, which are connected with nitrogen atom. They are more effective against staining fungi and moulds (Buschhaus 1992), but in higher concentrations they are able to suppress activity of rotting-fungi, as well. Sulfamides are used in organic solvents or water emulsions, and they are often added also to exterior coatings for the preventive treatment of structural elements without soil contact.<smiles>CN(C)S(=O)(=O)N(SC(F)(Cl)Cl)c1ccccc1</smiles>

Dichlofluanid<smiles>Cc1ccc(N(SC(F)(Cl)Cl)S(=O)(=O)O)cc1</smiles>

Tolylfluanid

Triazoles: Propiconazole \pm cis/trans(1-[[2-(2,4-dichlorophenyl)-4-propyl-1,3-dioxolan-2-yl]methyl]-1H-1,2,4-triazole), tebuconazole (Alpha-[2-(4-chlorophenyl)-ethyl]-alpha-(1,1dimethylethyl)-1H-1,2,4-triazole-1-ethanol) and azaconazole are well known organic fungicides often used in various commercial formulations for wood protection against all types of wood-degrading fungi (Wüstenhöfer et al. 1993). They are applied in non-polar and semi-polar organic solvents, or in water emulsions. The 1,2,4-triazoles are stable in environment, and have only a low toxicity to animals. Their efficacy can be increased with antioxidants or with metal chelators (Bakhsous et al. 2006). A typical natural antioxidant is caffeine (1,3,7-trimethylxanthine) which induces a strong alteration of cell wall architecture of fungi, inhibiting their growth. Its combination with propiconazole is effective against wood-destroying basidiomycetes (Lekounougou et al. 2007).

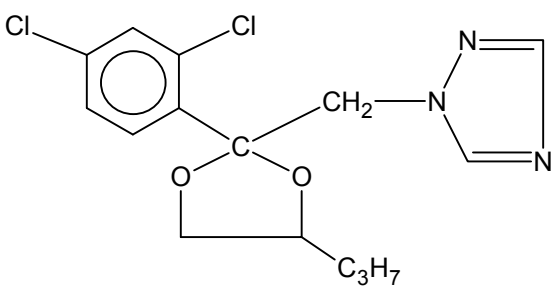

Propiconazole

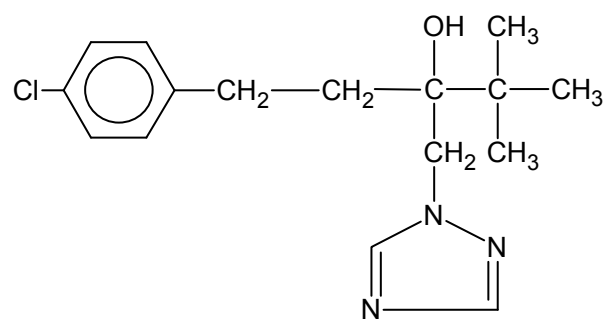

Tebuconazole

Metal azole complexes have been known from the $70^{\text {th }}$ years of the $20^{\text {th }}$ century. Now, after restriction of CCA salts, the use of copper in combination with organic co-biocide come into interest of more researches (Evans et al. 2008). Metal-centred azole complexes formed from propiconazole or tebuconazole with copper acetate, e.g. $\mathrm{Cu}$ (tebuconazole $)_{2}(\mathrm{OAc})_{2}$, or other metal substances create crystals which by more studies and patents have either lower or higher efficiency against fungi in comparison to original compounds. 
Natural substances: Interest in the exploration and use of natural products as fungicides is rapidly growing worldwide. Different natural substances are potentially suitable for wood protection before attack by fungi: plant extracts, essential oils, heartwood extractives, waxes and resins from bark, and other bioproducts, e.g. chitosan (Singh \& Singh 2010). However, industrial uptake of these compounds by wood preservation has been limited until now due to the following reasons: - incompatibility in efficacy of a compound on nutrient medium at screening tests and on wood in a practice; - narrow spectrum of fungicidal activity of some of these compounds, e.g. only against selected species of moulds; - variability in chemical composition; - incompatibility with legislation and registration of new compounds for market. In spite of these limitations, the potential is enormous for developing protection technologies based on the use of natural compounds as fungicides.

Natural organic compounds established as safe to human health and environment such as chitosan, essential oils, etc. have been investigated with aim of replacing inorganic and synthetic organic fungicides. Problems with their high leachibility from treated wood can be solved either with their in situ polymerization with wood tissues, e.g. by enzymatic polymerization of essential oil phenols with wood lignin, or by their nano-formulation in a form of micronized particles (Singh \& Singh 2010). Their fungicidal or commonly biological activity can also be improved using a combination of natural products (Maoz et al. 2007).

Essential oils are commercially used as perfumes, flavouring food additives, or pharmaceutical products. Some of them have good antifungal properties against wooddegrading fungi, e.g. cinnamon, geranium, lavender, oregano, thyme. Essential oils with phenolic or aldehyde and ketone components like thymol, carvone or carvacrol show evidently higher activity against wood-rotting basidiomycetes as those with hydrocarbon monoterpenes or ester monoterpenes (Amusant et al. 2009). Carvone, citronellol, geraniol, thymol and borneol are effective inhibitors of mould spore germination (Clausen et al. 2010).

Extracts from heartwood of more durable tropical or temperate wood species (Cupressus lusitanica, Dalbergia sissoo, Eperua falcata, E. grandiflora, Milicia excelsa, Taiwania cryptomerioides, Tectona grandis, Thuja plicata, etc.) contain bioactive compounds: polyphenolics (e.g. flavonoids, sterols), terpenics (e.g. cedrol, agathadiol, epimanool, bornyl acetate, cedrene), alkaloids, or stilbenes. These extracts inhibit activity of various types of wood-degrading fungi (Amusant et al. 2005, Chang et al. 2003, Kazemi et al. 2006, Mohareb et al. 2010b). However, alteration of their chemical structures during extraction processes from durable trees, during pressure or unpressured treatment of less durable wood species, or during exposure of treated wood products to environment can lead to loss of their original antifungal activity.

Chitosan is 1-4 linked heterogeneous polymers of D-glucosamine $\left(\mathrm{F}_{\mathrm{A}}=0\right)$, usually also with $\mathrm{N}$-acetyl-D-glucosamine units $\left(\mathrm{F}_{\mathrm{A}} \neq 0\right)$. This natural compound is derived from crustacean shells. To some extent is water soluble under acidic conditions. It can act both fungistatically and as a fungicide at higher concentrations (Eikenes et al. 2005).

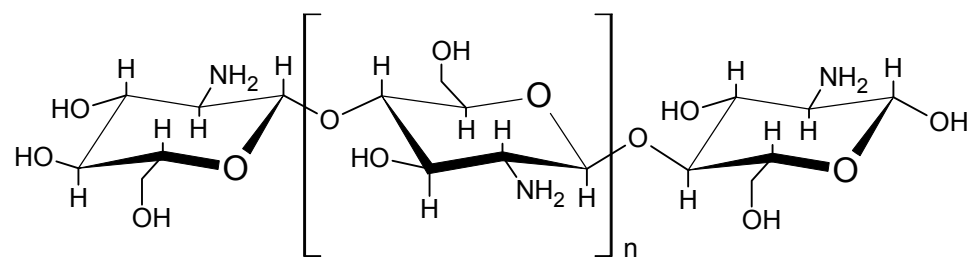

Chitosan (type $\mathrm{F}_{\mathrm{A}}=0$ ) 
Wood treated with 1-5 \% concentrations of chitosan proved effective against the brown-rot fungi Coniophora puteana and Gloeophyllum trabeum (Schmidt et al. 1995), and also against the white-rot fungus Trametes versicolor (Maoz \& Morrell 2004). Efficacy of chitosan depends also on its molecular weight (MW). Chitosan with lower MW has been found to be the most effective against Trametes versicolor and Poria placenta basidiomycetes (Mohareb \& Badawy 2008).

\section{Evaluation and testing of fungicides for wood protection in Slovakia}

In Slovakia, after its formation from Czechoslovakia in 1993, there has been a relatively poor interest for investigation of new active compounds with fungicide effects for wood preservation. Basic research at a limited level has been performed either in the capital Bratislava - in the Slovak Forest Products Research Institute, in the Chemical-Technological Faculty of the Slovak Technical University, in the Pharmacy faculty of the University of Comeniana, and simultaneously in Zvolen - in the Faculty of Wood Sciences and Technology of the Technical University in Zvolen.

The following compounds have been prepared (in Slovakia or also in Czech Republic) and tested by screening methods (poisoned agar-malt soil, poisoned filter papers, etc.) and European standards (EN 113, P ENV 839 - with treatment of wood samples) in the mycological laboratory of TU in Zvolen:

- more organic compounds with a potential fungicide efficiency (e.g. tributyltin-N,Ndiethyl-dithiocarbamate and other organotin-dithiocarbamates, copper and zinc dithiocarbamates, N-salicylidene-L-glutamato-copper(II) and other copper chelates, or 1,3,5-triazines with three identical hetero-cyclic groups),

- traditional boron fungicides in mixtures with inorganic ammonium salts (fire retardants),

- $\quad$ waste glycols modified with boron compounds (B-glycol-complexes), or with boron and waste copper compounds (Cu-B-glycol-complexes), together with selected additives.

Boric acid, disodium tetraborate, tributyltinnaphtenate (TBTN), 2thiocyanomethyltiobenzothiazole (TCMTB) and some other commercial fungicides have been used and tested also for antifungal protection of wooden composites - plywood, particleboards, etc. During the laboratory experiments interest was given to necessary changes related with technological parameters of their preparation (e.g. temperature and time of pressing), and on their effects against fungi. Tests showed that fungicides added to wooden composites in higher amounts provided successful antifungal activity. However, some fungicides had a negative influence on the moisture and strength properties of composite products with phenol-formaldehyde or melamine-urea-formaldehyde glues (Reinprecht \& Štefka 1989, Reinprecht \& Perlác 1995).

\subsection{Evaluation and antifungal tests of new organic compounds}

Between 1993 and 2008, the antifungal efficacy of newly prepared organotin compounds, metal dithiocarbamates, copper chelates and 1,3,5-triazines was tested at Zvolen's TU. These organic compounds were prepared in Bratislava in the Chemical-Technological Faculty of STU, or in the Pharmacy faculty of UC, and some of them also in Brno - Czech Republic in the Chemical faculty of VUT.

Organotin-dithiocarbamates: During 1993-1998, the antifungal efficacy of more organotin compounds, e.g. tributyltin-N,N-diethyl-dithiocarbamate (TBT-DEDTK), triphenyltin-N,N- 
diethyl-dithiocarbamate (TPT-DEDTK), tribenzyltin-N,N-diethyl-dithiocarbamate (TBzTDEDTK), tributyltin-N-pyrrolidinyl-dithiocarbamate (TBT-PoDTK), tributyltin-Npiperidinyl-dithiocarbamate (TBT-PiDTK), tributyltin-N-morpholinyl-dithiocarbamate (TBT-MfDTK), dibutyltin-di-N-pyrrolidinyl-dithiocarbamate (DBT-DPoDTK), tributyltinN,N-dipropyl-dithiocarbamate-dipropionate (TBT-DPrDTK-DPr), among others, was valued in screening and standard tests (Kizlink et al. 1996a, 1996b, Reinprecht 1996, Reinprecht \& Kizlink 1996, 1999), Their activity was compared with the commercial organotin fungicides bis/tributyltin/oxide (TBTO) and tributyltinnaphtenate (TBTN).

Anti-mould tests were carried out against a mixture of moulds (Aspergillus amstelodami, Aspergillus niger, Paecilomyces varioti, Penicillium brevicompactum, Penicillium cyclopium and Trichoderma viride), firstly by screening method on poisoned agar-malt soil and then by standard method STN 490604 with beech samples $50 \times 20 \times 5 \mathrm{~mm}$ treated with organotin compounds by dipping or pressure impregnation technology. Anti-decay tests were performed against the brown-rot fungi Serpula lacrymans and Coniophora puteana and the whiterot fungus Trametes versicolor, firstly by screening method on poisoned agar-malt soil and then by modified EN 113 standard using pressure impregnated beech samples $120 \times 8.5 \times 8.5 \mathrm{~mm}$. Before carrying out the antifungal tests, treated beech samples were naturally aged without contact with ground under an angle $45^{\circ}$ during the period of 0,2 or 4 months. From the organotin-dithiocarbamates tested, only the TBT-DEDTK had sufficient antifungal efficiency comparable with the commercial organotin compounds TBTO and TBTN (Reinprecht 1996).

Copper and zinc dithiocarbamates: Metal dithiocarbamates with aromatic or hetero-cyclic groups were prepared and then tested in screening tests against wood-destroying fungi Coniophora puteana and Trametes versicolor (Reinprecht et al. 2003). However, their antifungal efficacy, e.g. of copper/ $\mathrm{Cu}^{2+} /-\mathrm{N}$-morpholinyl-dithiocarbamate, zinc/ $\mathrm{Zn}^{2+} /-\mathrm{N}$-morpholinyldithiocarbamate, copper/ $\mathrm{Cu}^{2+} /-\mathrm{N}$-piperidinyl-dithiocarbamate, zinc/ $\mathrm{Zn}^{2+} /-\mathrm{N}$-piperidinyldithiocarbamate, and some others, was not sufficient. Antifungal effect of these metal dithiocarbamates was evidently lower in comparison with the organotin-dithiocarbamate TBT-DEDTK.

N-salicylidene-L-glutamato-copper(II) and other copper chelates: Antifungal and antimicrobial activity of various copper chelates does not show promising results against growth inhibition of wood-rotting fungi from a practical perspective (Kizlink et al. 2003, Reinprecht et al. 2003, Švajlenová et al. 1997). In screening tests the activity of newly prepared copper chelates, e.g. of (Cu/salicylidene/-glycin)-chelate, (Cu/chlorobenzaldehyde/-glycin)chelate, (Cu/anizaldehyde/-glycin)-chelate, (Cu/fural/-glycin)-chelate or $(\mathrm{Cu}$ /chlorbenzaldehyde/-beta-alanine)-chelate, against the fungi C. puteana and T. versicolor, was slightly lower that the well-known $\left(\mathrm{Cu}_{2} /\right.$ salycilidene/-beta-alanine)-chelate. However, antifungal activity of all these chelates was evidently lower in comparison with the commercial fungicide Tebuconazole (Reinprecht et al. 2003).

In antifungal screening tests with other copper chelates (Reinprecht et al. 2009), it was determined that activity of the N-salicylidene-L-glutamato-copper(II) chelate complexes $(\mathrm{Cu} / \mathrm{N}$-salicylidene-L-glutamato/X, where $\mathrm{X}=$ ligand) against the fungi Coniophora puteana and Trametes versicolor was better in comparison to the parent substance monohydrate diaqua/N-salicylidene-L-glutamato/copper(II) complex (Cu/N-sal-L-glu/. $\left.3 \mathrm{H}_{2} \mathrm{O}\right)$, and also to the free uncoordinated ligands $\mathrm{X}$ : urea, tiourea (TU), tetramethyltiourea (T-metu), imidazole (Im) or pyrazole (Pz) (Fig. 1 and 2). Activity of these copper chelates increased at higher concentrations from $0.1 \%$ to $1.0 \%$. Their efficiency was better against the brown-rot fungus C. puteana. However, activity of the tested copper chelate complexes was 4 to 20 times lower, when compared with the commercial fungicides IPBC and Tebuconazole. 

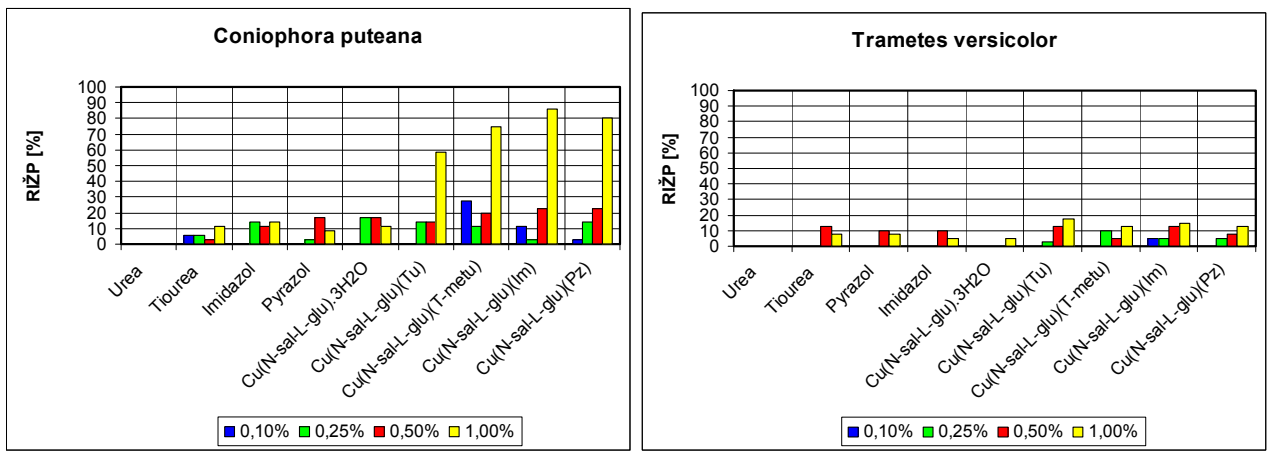

Notes:

- Screening tests with poisoned filter papers Whatman $3 \mathrm{CHR} \varnothing 14 \mathrm{~mm}$ treated with solutions of copper chelates or ligands $X$, which were located $20 \mathrm{~mm}$ from fungus inoculate

- Each value in the figure corresponds to the arithmetic mean of three samples.

Fig. 1. Growth inhibition indexes of fungus mycelium on the malt-agar soil (RIŽP) of selected N-salicylidene-L-glutamato-copper(II) chelates $\mathrm{Cu} / \mathrm{N}$-sal-L-glu/X between the 0 and $7^{\text {th }}$ day of screening test (Reinprecht et al. 2009)
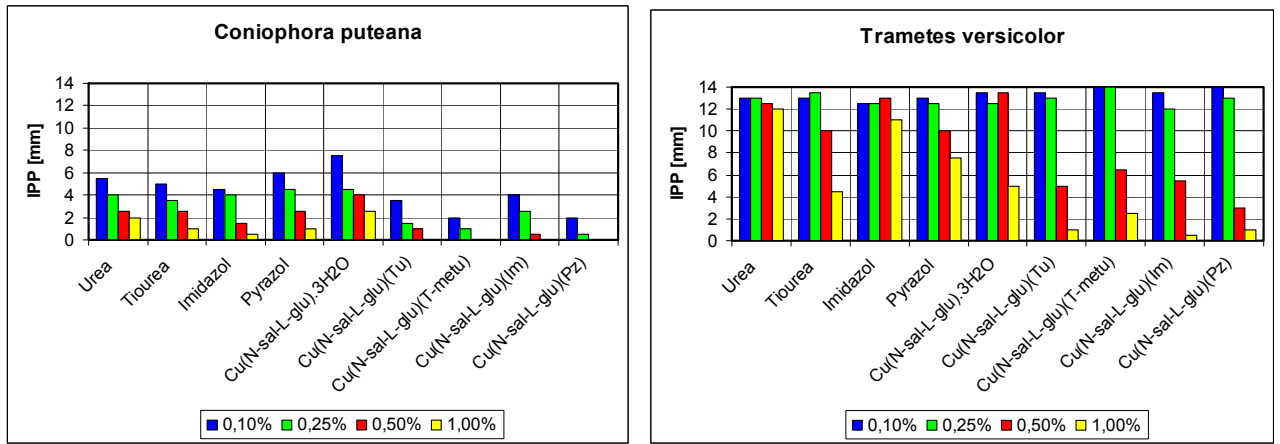

Notes:

- Screening tests with poisoned papers Whatman $3 \mathrm{CHR} \varnothing 14 \mathrm{~mm}$ treated with solutions of copper chelates, or ligands $X$

- $\quad$ Each value in the figure corresponds to the arithmetic mean of three samples.

Fig. 2. Indexes of fungus mycelium growth on poisoned filter papers (IPP) of selected Nsalicylidene-L-glutamato-copper(II) chelates $\mathrm{Cu} / \mathrm{N}$-sal-L-glu/X between the $7^{\text {th }}$ and $14^{\text {th }}$ day of screening test (Reinprecht et al. 2009)

1,3,5-triazines with three identical hetero-cyclic groups: Symmetrical triazines (s-triazines or 1,3,5-triazines) are a larger class of compounds exploited in many applications, most of them due to their biological properties (Afonso et al. 2006, Milata et al. 2001). New 1,3,5-triazines with three identical groups: benzotriazol-1/2-yl, imidazol-1-yl, pyrazolyl-1-yl, 3,5dimethylpyrazolyl-1-yl, 4,5-diphenylimidazol-1-yl, benzimidazolyl-1-yl, 2methylbenzimidazolyl-1-yl, or 2-phenylbenzimidazolyl-1-yl were synthesised. Their biological activity against wood-destroying fungi Serpula lacrymans, Coniophora puteana and 
Trametes versicolor was tested in screening tests by the method of poisoned filter papers. $S$. lacrymans occurred as the most sensitive fungus on presence of 1,3,5-triazines.

Triazines with three imidazole or three 4,5-diphenylimidazole groups were a slightly more effective than other ones. However, their efficacy in comparison with the commercial fungicides Tebuconazole and IPBC was insufficient (Milata et al. - in press).

\subsection{Antifungal efficiency of boron compounds in mixtures with inorganic ammonium salts}

The aim of the experiment was to propose a suitable type of the preservative for treatment of wood in interiors with a complete fungicide, insecticide and fire-retardant effect (Reinprecht \& Pánek 2007). Chemicals based on boron (boric acid and disodium tetraborate decahydrate /borax/) were used as biocides "fungicide + insecticide", and chemicals based on inorganic ammonium salts (ammonium sulphate and dihydrogenammonium phosphate) were used as fire-retardants. Fungicide efficacy of inorganic boron-amino preservatives with different portions of boron and ammonium salts was valued against the wood-destroying fungi Coniophora puteana and Trametes versicolor (by screening test, and then by the P ENV 839 - Tab. 2), and also against the mixture of moulds Alternaria alternata, Aspergillus niger, Aspergillus amstelodami, Penicillium cyclopium and Penicillium brevi-compactum (by screening test, and then by the Slovak standard STN 490604 - Tab. 3).

\begin{tabular}{|c|c|c|c|c|}
\hline Fungus & $\begin{array}{c}\text { Wood } \\
\text { preservative }\end{array}$ & $\begin{array}{c}\text { Concentration of } \\
\text { boron compounds } \\
\text { in the preservative } \\
\mathrm{C}_{\mathrm{B}} \\
(\%)\end{array}$ & $\begin{array}{c}\text { Retention of } \\
\text { boron } \\
\text { compounds by } \\
\text { wood } \\
\mathrm{R}_{\mathrm{B}}\left(\mathrm{g} / \mathrm{m}^{2}\right) \\
\end{array}$ & $\begin{array}{c}\text { Weight loss of } \\
\text { sap-pine wood } \\
\text { samples at } \\
\text { decay } \\
\Delta \mathrm{m}(\%)\end{array}$ \\
\hline \multirow{6}{*}{$\begin{array}{l}\text { Coniophora } \\
\text { puteana }\end{array}$} & AS & - & - & 20.80 \\
\hline & \multirow{5}{*}{$\mathrm{AS}+\mathrm{B}$} & 0.25 & 0.45 & 18.92 \\
\hline & & 0.5 & 1.07 & 19.03 \\
\hline & & 1.0 & 1.96 & 12.40 \\
\hline & & 2.5 & 4.06 & 8.15 \\
\hline & & 5.0 & 8.76 & 2.30 \\
\hline \multirow{6}{*}{$\begin{array}{l}\text { Trametes } \\
\text { versicolor }\end{array}$} & AS & - & - & 12.22 \\
\hline & \multirow{5}{*}{$\mathrm{AS}+\mathrm{B}$} & 0.25 & 0.47 & 14.11 \\
\hline & & 0.5 & 1.07 & 11.69 \\
\hline & & 1.0 & 1.75 & 7.74 \\
\hline & & 2.5 & 4.52 & 4.32 \\
\hline & & 5.0 & 8.94 & 3.54 \\
\hline
\end{tabular}

Notes:

- $\quad \mathrm{AS}=$ ammonium salt $\left(50 \% \mathrm{NH}_{4} \mathrm{H}_{2} \mathrm{PO}_{4}\right.$ - dihydrogenammonium phosphate, and $50 \% / \mathrm{NH}_{4} / 2 \mathrm{SO}_{4}$ - ammonium sulphate) applied in the form of $35 \%$ water solution.

- $\quad B=$ mixture of boron compounds 1:1 $\left(50 \% \mathrm{H}_{3} \mathrm{BO}_{3}\right.$ - boric acid, and $50 \% \mathrm{Na}_{2} \mathrm{~B}_{4} \mathrm{O}_{7} \cdot 10 \mathrm{H}_{2} \mathrm{O}$ disodium tetraborate decahydrate), added to the AS preservative in various amounts.

- Each value in the table corresponds to the arithmetic mean of four samples.

- Weight losses of control untreated samples by C. puteana $=34.36 \%$, and by T. versicolor $=20.72 \%$.

Table 2. Fungicide efficacy of wood preservatives containing ammonium salts (AS) and boron compounds (B) - standard test by P ENV 839 (Reinprecht \& Pánek 2007) 
Results of the screening and standard mycological tests showed that sufficient efficacy of the inorganic boron-amino preservative against brown-rot (C. puteana) and white-rot ( $T$. versicolor) fungi can be achieved only if at least $5 \%$ amount of boron compounds $(2.5 \%$ of boric acid and $2.5 \%$ of borax) are used. In this situation the weight losses of treated sap-pine samples were under $3 \%$, or under $4 \%$ (Tab. 2). On the other hand, the $5 \%$ concentration of boron in the boron-amino preservatives is not a guarantee of a sufficient efficacy of treated wood against the mould attack (Tab. 3). This can be explained by a lower efficacy of boron against moulds than against wood-destroying fungi. An alternative explanation might be that the presence of nitrogen in ammonium salts can often support growth of moulds.

\begin{tabular}{|c|c|c|c|c|}
\hline $\begin{array}{l}\text { Mixture of } \\
\text { moulds }\end{array}$ & $\begin{array}{c}\text { Wood } \\
\text { preservative }\end{array}$ & $\begin{array}{l}\text { Concentration of } \\
\text { boron compounds } \\
\text { in the } \\
\text { preservative } \\
\mathrm{C}_{\mathrm{B}} \\
(\%) \\
\end{array}$ & $\begin{array}{c}\text { Retention of } \\
\text { boron } \\
\text { compounds by } \\
\text { wood } \\
\mathrm{R}_{\mathrm{B}} \\
\left(\mathrm{g} / \mathrm{m}^{2}\right) \\
\end{array}$ & $\begin{array}{l}\text { Growth of } \\
\text { moulds on sap- } \\
\text { pine wood } \\
\text { surfaces } \\
\text { Moulds } \\
(0-4) \\
\end{array}$ \\
\hline \multirow{6}{*}{$\begin{array}{l}\text { A. alternata } \\
\text { A. amstelodami } \\
\text { A. niger } \\
\text { P. cyclopium } \\
\text { P. brevi- } \\
\text { compactum }\end{array}$} & AS & - & - & 4 \\
\hline & \multirow{5}{*}{$\mathrm{AS}+\mathrm{B}$} & 0.25 & 0.43 & 4 \\
\hline & & 0.5 & 1.02 & 3.8 \\
\hline & & 1.0 & 2.11 & 3.8 \\
\hline & & 2.5 & 4.18 & 3.6 \\
\hline & & 5.0 & 8.94 & 3.2 \\
\hline
\end{tabular}

Notes:

- $\quad$ Each value in the table corresponds to the arithmetic mean of 20 samples.

- Growth of moulds on untreated samples was always maximal (Moulds $=4$ ), it means that more as $50 \%$ of wood surfaces was covered with microscopic fungi - moulds.

Table 3. Efficacy of wood preservatives containing ammonium salts (AS) and boron compounds (B) against moulds - test by the national standard STN 490604 (Reinprecht \& Pánek 2007)

\subsection{Antifungal efficiency of waste glycols modified either with boron compounds (B- glycol-complexes), or with boron and waste copper compounds (Cu-B-glycol- complexes)}

Exploitation of metals $(\mathrm{Cu}, \mathrm{Cd}, \mathrm{Co}, \mathrm{Fe}, \mathrm{Mn}, \mathrm{Ni}, \mathrm{Pb}, \mathrm{Ti}, \mathrm{V}, \mathrm{W}, \mathrm{Zn}, \mathrm{Zr})$ and their salts which can be obtained by treatment of electrical and electronical (E\&E) wastes is now one of the main interests of researchers and technical workers. This interest is a direct result of the European Union Direction No 2002/96/ES (about wastes from electrical and electronical devices), which gives not only demands on recycling of metals obtained from wastes, but also informs about possibilities of how to use salts of these metals and their mixtures for chemical products. Some metal salts from electrical and electronical wastes can be used as wood preservatives, plant preservatives, anti-corrosive protective agents of steels, or stabilizing agents of plastics (Edenbaum 1992).

The aim of the experiment was to prepare modified waste substances (copper and glycols) obtained from electrical and cooling waste products, and use them as wood preservatives 
with antifungal effects (Reinprecht \& Kizlink 2007). Waste glycols "Fridex" were mixed with boron compounds $\mathrm{H}_{3} \mathrm{BO}_{3}$ and $\mathrm{Na}_{2} \mathrm{~B}_{4} \mathrm{O}_{7} \cdot 10 \mathrm{H}_{2} \mathrm{O}$ (B-glycol-complexes), or also with copper compounds (Cu-B-glycol-complexes). Both types of these compounds were modified as well as with the QAC fungicide "Althosan MBO - lauryl-benzyl-dimethyl-ammonium chloride", or also with some other additives. For complexes of the type I., II. and III., the $\mathrm{Cu}$ (waterwaste) products, or also the cupric-salicylate, were added (Tab. 4).

1) $20 \%$ Boron-glycol $+80 \%$ Ethanol-Water

2) $20 \%$ Boron-phosphor-glycol $+80 \%$ Ethanol-Water

3) $10 \%$ Boron-glycol +10\% Boron-phosphor-glycol $+80 \%$ Ethanol-Water

4) $3 \% \mathrm{H}_{3} \mathrm{BO}_{3}+2 \% \mathrm{Na}_{2} \mathrm{~B}_{4} \mathrm{O}_{7} .10 \mathrm{H}_{2} \mathrm{O}+5 \%$ Fridex $+1 \%$ Althosan $\mathrm{MBO}+0.25 \% \mathrm{KSD}+88.75 \%$ Water

5) $3 \% \mathrm{H}_{3} \mathrm{BO}_{3}+2 \% \mathrm{Na}_{2} \mathrm{~B}_{4} \mathrm{O}_{7} .10 \mathrm{H}_{2} \mathrm{O}+5 \%$ Fridex $+2 \%$ Althosan $\mathrm{MBO}+0.25 \% \mathrm{KSD}+87.75 \%$ Water

6) $3 \% \mathrm{H}_{3} \mathrm{BO}_{3}+2 \% \mathrm{Na}_{2} \mathrm{~B}_{4} \mathrm{O}_{7} \cdot 10 \mathrm{H}_{2} \mathrm{O}+5 \%$ Fridex $+2 \%$ A0lthosan $\mathrm{MBO}+1 \% \mathrm{KSD}+1 \%$ UR $+86 \%$ Water

7) $3.5 \% \mathrm{H}_{3} \mathrm{BO}_{3}+2 \% \mathrm{Na}_{2} \mathrm{~B}_{4} \mathrm{O}_{7} \cdot 10 \mathrm{H}_{2} \mathrm{O}+5 \%$ Fridex $+2 \%$ Althosan $\mathrm{MBO}+1 \% \mathrm{UR}+86.5 \%$ Water

8) $3 \% \mathrm{H}_{3} \mathrm{BO}_{3}+1.5 \% \mathrm{Na}_{2} \mathrm{~B}_{4} \mathrm{O}_{7} .10 \mathrm{H}_{2} \mathrm{O}+5 \%$ Fridex $+2 \%$ Althosan $\mathrm{MBO}+0.5 \% \mathrm{UR}+88 \%$ Water

9) $3 \% \mathrm{H}_{3} \mathrm{BO}_{3}+1.5 \% \mathrm{Na}_{2} \mathrm{~B}_{4} \mathrm{O}_{7} .10 \mathrm{H}_{2} \mathrm{O}+5 \%$ Fridex $+2 \%$ Althosan $\mathrm{MBO}+1 \%$ TUR $+87.5 \%$ Water

10) $3.5 \% \mathrm{H}_{3} \mathrm{BO}_{3}+2 \% \mathrm{Na}_{2} \mathrm{~B}_{4} \mathrm{O}_{7} .10 \mathrm{H}_{2} \mathrm{O}+5 \%$ Fridex $+2 \%$ Althosan $\mathrm{MBO}+1 \%$ TUR $+86.5 \%$ Water

11) $3 \% \mathrm{Cu}(\mathrm{OH})_{2} \cdot \mathrm{CuCO}_{3}+2 \% \mathrm{H}_{3} \mathrm{BO}_{3}+5 \%$ Fridex $+5 \%$ Althosan $\mathrm{MBO}+5 \% \mathrm{MEA}+80 \%$ Water

12) $3 \% \mathrm{Cu}(\mathrm{OH})_{2} \cdot \mathrm{CuCO}_{3}+2 \% \mathrm{H}_{3} \mathrm{BO}_{3}+8 \%$ Fridex $+2 \%$ Althosan $\mathrm{MBO}+5 \% \mathrm{MEA}+80 \%$ Water

13) $3 \% \mathrm{Cu}(\mathrm{OH})_{2}+2 \% \mathrm{H}_{3} \mathrm{BO}_{3}+8 \%$ Fridex $+2 \%$ Althosan $\mathrm{MBO}+5 \% \mathrm{MEA}+80 \%$ Water

14) Complex I. $=1 \% \mathrm{CuCO}_{3}+1 \% \mathrm{H}_{3} \mathrm{BO}_{3}+3 \% \mathrm{MEA}+5 \%$ glycol $+90 \% \mathrm{Cu}$ (water-waste)

15) Complex II. $=1 \% \mathrm{Cu}(\mathrm{OH})_{2} \cdot \mathrm{CuCO}_{3}+1 \% \mathrm{H}_{3} \mathrm{BO}_{3}+3 \% \mathrm{MEA}+5 \%$ glycol $+90 \% \mathrm{Cu}($ water-waste)

16) Complex III. = $95 \%$ Complex II. $+5 \%$ cupric-salicylate

Notes:

- Boron-glycol was prepared by the reaction from boric acid, borax and ethyleneglycol, and boronphosphor-glycol was prepared by the reaction from boric acid, borax, phosphoric acid and propyleneglycol (Bukovský et al. 1998).

- Additives: Fridex (waste glycols), $\mathrm{Cu}$ (water-waste) waste products with approximately $0.7 \%$ of copper, Althosan $\mathrm{MBO}$ (QAC = lauryl-benzyl-dimethyl-ammonium chloride), $\mathrm{KSD}$ (potassiumhydrogensulphate), UR (urea), TUR (thiourea), MEA (monoethanolamine), SA (sulphuric acid) $\rightarrow$ only drops for $\mathrm{pH}$ value regulation between 7 and 10 .

Table 4. Composition of the B-glycol and Cu-B-glycol complexes (Reinprecht \& Kizlink 2007)

Efficacy of all prepared complexes No. 1-16 against the brown-rot fungus Coniophora puteana and the white-rot fungus Trametes versicolor was tested by the method of poisoned filter papers Whatman $3 \mathrm{CHR} \varnothing 14 \mathrm{~mm}$, using $10 \%, 33 \%$ or $100 \%$ water solution of these complexes. Three poisoned filter papers and one control paper were situated on agar-malt soil in each Petri dishes with a diameter of $120 \mathrm{~mm}$, where inoculate of used fungus was previously situated in its centre (Fig. 3). Table 5 presents results obtained with the $10 \%$ solutions of tested compounds.

Antifungal effect of the $\mathrm{Cu}$-B-glycol-complexes was nearly comparable with the standard Wolmanit CX-H 200 (mixture of $2.5 \% \mathrm{Cu}-\mathrm{HDO}, 4.2 \% \mathrm{Cu}(\mathrm{OH})_{2} \cdot \mathrm{CuCO}_{3}$ and $25 \% \mathrm{H}_{3} \mathrm{BO}_{3}$ in water). Copper in the glycol-complexes had an apparent positive antifungal effect, comparing a higher efficiency of the Cu-B-glycols (No. 11-13) with a lower efficiency of the B-glycols (No. 4-10). Activity of copper was slightly better against the white-rot fungus $T$. versicolor than against the brown-rot fungus C. puteana (No. 11-13). However, the complexes I., II. and III., based on the waste copper products: $\mathrm{Cu}(\mathrm{OH})_{2} \cdot \mathrm{CuCO}_{3}-\mathrm{H}_{3} \mathrm{BO}_{3}$-ethanolamine- 
glycol- $\mathrm{Cu}$ (water-waste) and $\mathrm{CuCO}_{3}-\mathrm{H}_{3} \mathrm{BO}_{3}$-ethanolamine-glycol-Cu(water-waste), and without the QAC "Althosan $\mathrm{MBO}$ ", were less effective against the wood-destroying fungi, specially against the $T$. versicolor (No. 14-16).

\begin{tabular}{|c|c|c|c|c|c|c|c|c|}
\hline \multirow{2}{*}{$\begin{array}{l}\text { Tested } \\
\text { compound } \\
\text { c }=10 \%\end{array}$} & \multicolumn{4}{|c|}{ Coniophora puteana } & \multicolumn{4}{|c|}{ Trametes versicolor } \\
\hline & \multicolumn{2}{|c|}{$\begin{array}{l}\text { Inhibition zone } \\
(\mathrm{mm}) \\
7^{\text {th }} \text { day } 14^{\text {th }} \text { day }\end{array}$} & \multicolumn{2}{|c|}{$\begin{array}{l}\text { Growth on papers } \\
(\mathrm{mm}) \\
7^{\text {th }} \text { day } 14^{\text {th }} \text { day }\end{array}$} & \multicolumn{2}{|c|}{$\begin{array}{l}\text { Inhibition zone } \\
(\mathrm{mm}) \\
7^{\text {th }} \text { day } 14^{\text {th }} \text { day }\end{array}$} & \multicolumn{2}{|c|}{$\begin{array}{l}\text { Growth on papers } \\
(\mathrm{mm}) \\
7^{\text {th }} \text { day } 14^{\text {th }} \text { day }\end{array}$} \\
\hline \multicolumn{9}{|l|}{ B-glycol complexes } \\
\hline 1 & $1-5$ & 0 & 0 & $8-12$ & $0-2$ & 0 & $0-2$ & $8-14$ \\
\hline 2 & $1-3$ & 0 & 0 & $10-12$ & 0 & 0 & $1-4$ & 14 \\
\hline 3 & $1-3$ & 0 & 0 & $9-11$ & 0 & 0 & $1-4$ & $12-14$ \\
\hline 4 & $4-6$ & 0 & 0 & $5-7$ & $0-4$ & 0 & 0 & $2-7$ \\
\hline 5 & $4-8$ & 0 & 0 & $4-7$ & $1-4$ & 0 & 0 & $1-4$ \\
\hline 6 & $3-4$ & 0 & 0 & $5-9$ & $1-2$ & 0 & 0 & $2-6$ \\
\hline 7 & $2-4$ & 0 & 0 & $6-11$ & $0-1$ & 0 & 0 & $3-7$ \\
\hline 8 & $3-7$ & 0 & 0 & $5-8$ & $0-2$ & 0 & 0 & $3-7$ \\
\hline 9 & $2-7$ & 0 & 0 & $4-9$ & $1-3$ & 0 & 0 & $2-6$ \\
\hline 10 & $3-6$ & 0 & 0 & $5-8$ & $2-3$ & 0 & 0 & $2-4$ \\
\hline \multicolumn{9}{|l|}{ Cu-B-glycol complexes } \\
\hline 11 & $6-12$ & 0 & 0 & $3-5$ & $5-8$ & $2-3$ & 0 & 0 \\
\hline 12 & $5-10$ & 0 & 0 & $2-5$ & $6-9$ & $1-2$ & 0 & $0-3$ \\
\hline 13 & $6-10$ & 0 & 0 & $2-5$ & $4-7$ & $0-1$ & 0 & $0-2$ \\
\hline 14 & $7-12$ & 0 & 0 & $0-6$ & $0-2$ & 0 & $0-1$ & $6-10$ \\
\hline 15 & $4-6$ & 0 & 0 & $4-7$ & $0-2$ & 0 & $0-2$ & $8-12$ \\
\hline 16 & $5-10$ & 0 & 0 & $2-5$ & $0-3$ & 0 & $0-2$ & $10-12$ \\
\hline \multicolumn{9}{|l|}{ Standard } \\
\hline Controls & 0 & 0 & $0-4$ & 14 & 0 & 0 & $10-14$ & 14 \\
\hline
\end{tabular}

Note:

- Each value in the table corresponds to the arithmetic mean of nine poisoned papers situated in three Petri dishes.

Table 5. Screenings of the antifungal efficacy of B-glycol and Cu-B-glycol complexes against the fungi C. puteana and T. versicolor, at using their $\mathrm{c}=10 \%$ water solutions in poisoned filter papers (Reinprecht \& Kizlink 2007)

Waste glycol compounds and waste copper compounds can be in exceptional cases used for preparation of wood preservatives: glycols as solvents and copper as fungicides. However, the chemical composition of all waste compounds used as wood preservatives with fungicide activity has to be exactly known, because it is very important from the ecological aspects and also from the point of view of the stability and durability of antifungal or other protection effects. 

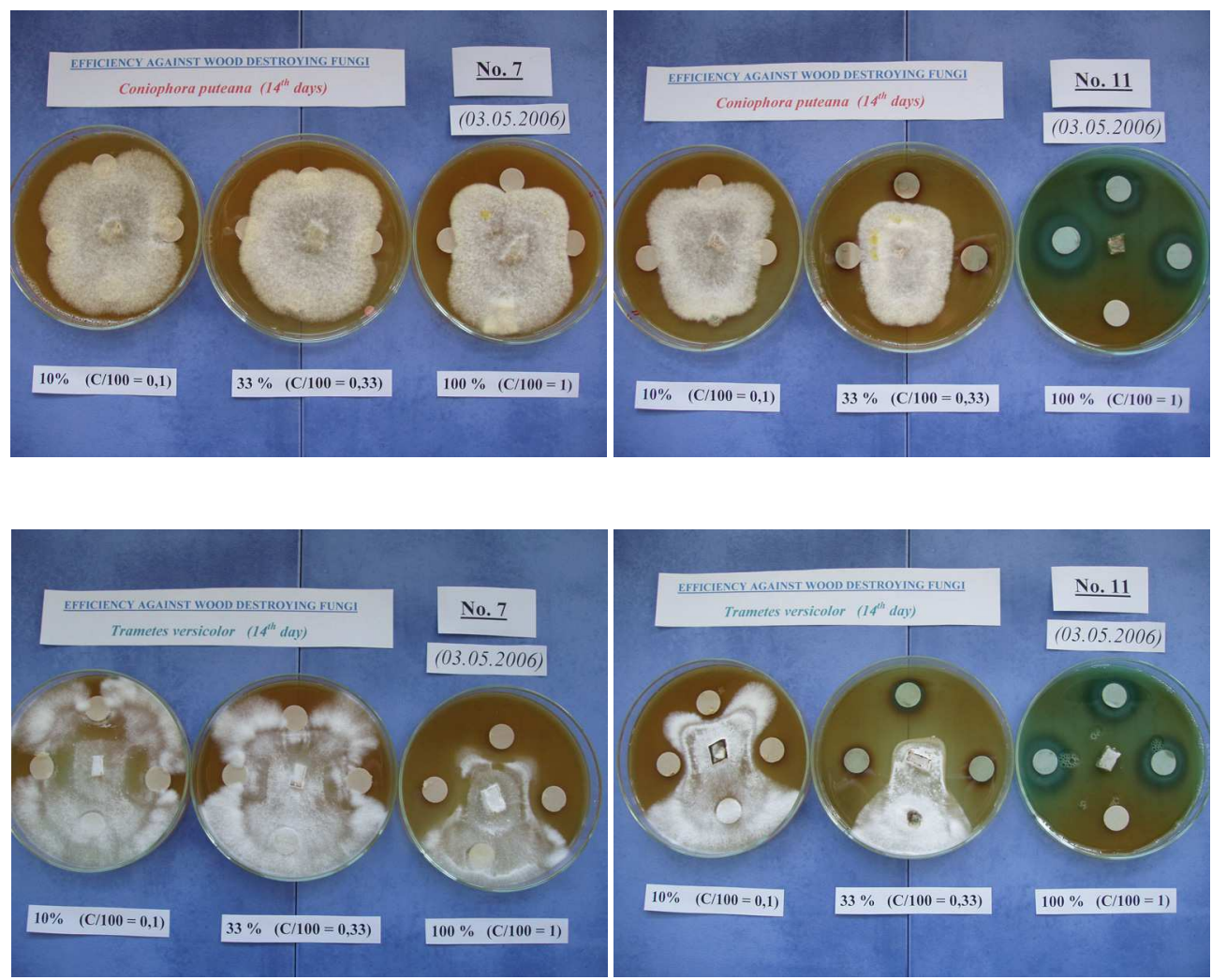

Fig. 3. Activity of the B-glycol-complex (No. 7) and the Cu-B-glycol complex (No. 11) against the fungi C. puteana and T. versicolor, determined by the screening test with poisoned filter papers in the $14^{\text {th }}$ day

\section{Conclusion}

In present various types of inorganic and organic fungicides are commonly used for preservation of wood and wooden composites against moulds, staining fungi and rottingfungi. However, in future the timber industry will need new environmentally more friendly preservatives. Among the most perspective fungicides probably belong the natural substances (chitosan, essential oils, ...) and synthetically prepared organic compounds (hetero-cycles, carbamates, ...). Research in these fields have to be complex with aim to give on market only healthy-safe, stable and effective products.

\section{Acknowledgments}

The author would like to express thanks the Ministry of Education of the Slovak Republic (project VEGA 1/0421/10) for support of this Chapter in the book Fungicides. 


\section{References}

Afonso, C. A. M., Lourenço, N. M. T., Rosatella, A. de A. (2006): Synthesis of 2,4,6trisubstituted-1,3,5-Triazines. Molecules, 11: 81-102.

Akhtari, M., Arefkhani, M. (2010): Application of nanotechnology in wood preservation. The International Research Group on Wood Protection, (Biarritz - France), IRG/WP 1030542, 7 p.

Amusant, N., Moretti, C., Richard, B., Prost, E., Nuzillard, J. M., Thévenon, M. (2005): Chemical compounds from Eperua falcate and Eperua grandiflora heartwood and their biological activities against wood destroying fungus (Coriolus versicolor). The International Research Group on Wood Protection, (Bangalore - India), IRG/WP 0530373, $16 \mathrm{p}$.

Amusant, N., Thévenon, M-F., Leménager, N., Wozniak, E. (2009): Potential of antifungal and antitermic activity of several essential oils. The International Research Group on Wood Protection, (Beijing - China), IRG/WP 09-30515, 16 p.

Arantes, V., Goodell, B., Milagres, A. M. F., Qian Y. (2010): Fungal attack on lignin and cellulose: Elucidation of brown- and white-rot mechanisms comparing biomimetic and in-vivo degradation patterns. The International Research Group on Wood Protection, (Biarritz - France), IRG/WP 10-10714, 20 p.

Babuder, G., Petrič, M., Čadez, F., Humar, M., Pohleven, F. (2004): Fungicidal properties of boron containing preservative Borosol 9. The International Research Group on Wood Preservation, (Ljubljana - Slovenia), IRG/WP 04-30348, 6 p.

Bakhsous, B., Dumarcay, S., Gelhaye, E., Gérardin, P. (2006): Investigation of new wood preservation formulations based on synergies between antioxidant, 2-HPNO and propiconazole. The International Research Group on Wood Protection, (Tromso Norway), IRG/WP 06-30401, 8 p.

Bota, P., Baines, E., Mead, A, Watkinson, S. C. (2010): Antifungal and wood preservative efficacy of IPBC is enhanced by $\alpha$-aminoisobutyric acid. The International Research Group on Wood Protection, (Biarritz - France), IRG/WP 10-30544, 10 p.

Brischke, C. R., Rapp, A. O. (2008): Dose- response relationships between wood moisture content, wood temperature and fungal decay determined for 23 European field test sites. Wood Science and Technology, 42:507-518.

Bukovský, L., Wasserbauer, R., Pechová, D., Cvengroš, J., Rabas, V. (1998): Př́ipravek na ochranu dřeva a zpusoby jeho výroby / Product for wood preservation a modes of its preparation/. Patents: CZ 284.376, SK 280.380, (1999): CA 131, 166533.

Buschhaus, H-U. (1992): Tolylfluanid - fungicide against blue stain in service. The International Research Group on Wood Preservation, IRG/WP 3736.

Carll, C., Highley, T. L. (1999): Decay of wood and wood-based products above ground in buildings. Journal of Testing and Evaluation, 27(2): 150-158.

Cassens, D. L., Eslyn, W. E. (1981): Fungicides to prevent sapstain and mold on hardwood lumber. Forest Products Journal, 31(9): 39-42.

Chang, S-T., Wang, S-Y., Kuo, Y-H. (2003): Resource and bioactive substances from Taiwania (Taiwania cryptomeriodes). Journal of Wood Science, 49: 1-4.

Chen, G. (2010): Laboratory evaluation of borate amine borate derivatives in wood for fungal decay. The International Research Group on Wood Protection, (Biarritz - France), IRG/WP 10-30543, 20 p. 
Choi, S. M., Ruddick, J. N. R., Morris, P. I. (2001): The possible role of mobile CCA components in preventing spore germination in checked surfaces, in treated wood exposed above ground. The International Research Group on Wood Preservation, (Nara - Japan), IRG/WP 01-30263, 16 p.

Clausen, C. A., Woodward, B. M., Yang, V. W. (2010): Antifungal essential oil metabolites. The International Research Group on Wood Protection, (Biarritz - France), IRG/WP 1030531, 9 p.

Dahlgren, S-E., Hartford, W. H. (1972): Kinetics and mechanism of fixation of Cu-Cr-As wood preservatives. Part II. Fixation of Boliden K33. Holzforschung, 26(3): 105-113.

Dickinson, D. J., Murphy, R. J. (1989): Development of boron wood based preservatives. Res. Brit. Wood Pres. Assoc. Ann. Conv.: 35-44.

Eaton, R. A., Hale, M. D. C. (1993): Wood - decay, pests and protection. Chapman \& Hall, London, $546 \mathrm{p}$.

Edenbaum, J. (1992): Plastics additives and modifier handbook. Van Nostrand-Reinhold, New York.

Eikenes, M, Alfredsen, G., Lanroy, E., Militz, H., Kreber, B., Chittenden, C. (2005): Chitosan for wood protection - state of the art. The International Research Group on Wood Protection, (Bangalore - India), IRG/WP 05-30378, 18 p.

Ellis, J. R., Jayachandran, K., Nicholas, D. (2007): Silver - the next generation wood preservative. The International Research Group on Wood Protection, (Wyoming - USA), IRG/WP/07-30419, $7 \mathrm{p}$.

Eriksson, K-E. L., Blanchette, R. A., Ander. P. (1990): Microbial and enzymatic degradation of wood and wood components. Springer Series in Wood Science, Berlin Heidelberg New York, $407 \mathrm{p}$.

European standards: EN 113, EN 350-2, EN 335-1, EN 460, P ENV 839

Evans, P. D. (2003): Emerging technologies in wood protection. Forest Products Journal, 53(1): 14-22.

Evans, P. D., Schmalzl, K. J., Forsyth, C. M., Fallon, G. D., Schmid, S., Bendixen, B., Heimdal, S. (2008): Formation and structure of metal azole complexes. The International Research Group on Wood Protection, (Istanbul - Turkey), IRG/WP 08-30469, 12 p.

Fargašová, A., Reinprecht, L., Kizlink, J. (1997): Efficiency of organotin dithiocarbamate derivatives against wood destroying fungi. Biologia, 52(3): 451-455.

Fengel, D., Wegener, G. (1984): Wood - chemistry, ultrastructure, reactions. de Gruyter Berlin, $237 \mathrm{p}$.

Foliente, G. R. H., Leicester, C. H., Wang, C., Mackenzie, C., Cole, I. (2002): Durability design for wood construction. Forest Products Journal, 52(1): 10-19.

Fougerousee, M. (1985): Protection of logs and sawn timber. In: Preservation of Timber in the Tropics, (ed. W. P. K. Findlay), Martinus Nijhoff, pp. 75-119.

Furuno, T., Imamura, Y. (1998): Combinations of wood and silicate. Part 6: Biological resistance of wood-mineral composites using water glass-boron compound system. Wood Science and Technology, 32: 161-170.

Gérardin, P., Baya, M., Delbarre, N., Diouf, P. N., Perrin, D., Soulounganga, P., Gelhaye, E., Jacquot, J. P., Rapin, C. (2002): Evaluation of tropolone as a wood preservative activity and mode of action. The International Research Group on Wood Preservation, (Cardiff - UK), IRG/WP 02-30282, 13 p. 
Ghosh, S. C., Mai, C., Militz, H. (2008): The efficacy of commercial silicones against blue stain and mould fungi in wood. The International Research Group on Wood Protection, (Istanbul - Turkey), IRG/WP 08-30471, 17 p.

Goodell, B., Daniel, G., Jellison, J., Qian, Y. (2007): Chelator-mediated Fenton chemistry in wood degraded fungi. The International Research Group on Wood Protection, (Wyoming - USA), IRG/WP 07-10618, $10 \mathrm{p}$.

Hansen, J. (1984): IPBC - a new fungicide for wood protection. The International Research Group on Wood Preservation, IRG/WP 3295.

Hastrup, A. Ch. S., Green, III. F., Clausen, C., Jensen, B. (2005): Serpula lacrymans - the dry rot fungus tolerance towards copper-based wood preservatives. The International Research Group on Wood Protection, (Bangalore - India), IRG/WP 05-10555, 7 p.

Hastrup, A. Ch. S., Jensen, B., Gree III., F. (2010): Chemical mediated depolymerization of cotton cellulose for the understanding of non-enzymatic decay. The International Research Group on Wood Protection, (Biarritz - France), IRG/WP 10-10731, 12 p.

Härtner, H., Barth, V. (1996): Effectiveness and synergistic effects between copper and polymer betaine. The International Research Group on Wood Preservation, IRG/WP 9630097.

Hegarty, B., Yu, B., Leightley, L. (1997): The suitability of isothiazolone microemulsions as long-term wood preservatives. The International Research Group on Wood Preservation, IRG/WP 97-30150.

Hill, C. A. S. (2006): Wood modification - chemical, thermal and other processes. John Wiley \& Sons Ltd, Chichester UK, 239 p.

Humar, M., Petric, M., Pohleven, F. (2001): Changes of the pH value of impregnated wood during exposure to wood-rotting fungi. Holz als Roh- und Werkstoff, 59: 288-293.

Humphrey, D. G., Duggan, P. J., Tyndall, E. M., Carr, J. M., Cookson, L. J. (2002): New boron-based biocides for the protection of wood. The International Research Group on Wood Preservation, (Cardiff - UK), IRG/WP 02-30283, 11 p.

Jüngel, P., Melcher, E. (2006): The role of chromium in wood preservation - the situation versus results concerning the biological efficacy. The International Research Group on Wood Protection, (Tromso - Norway), IRG/WP 06-30397, 9 p.

Jüngel, P., Hellkamp, S. (2008): The role of chromium in wood preservatives under BPD a review and the current situation in Europe. The International Research Group on Wood Protection, (Istanbul - Turkey), IRG/WP 08-30468, 10 p.

Kartal, S. N., Hwang, W-J., Shinoda, K., Imamura, Y. (2004): Decay and termite resistance of wood treated with boron-containing quarternary ammonia compound, didecyl dimetyl ammonium tetrafluoroborate (DBF) incorporated with acryl-silicon type resin. The International Research Group on Wood Preservation, (Ljubljana - Slovenia), IRG/WP 04-03334, $15 \mathrm{p}$.

Kartal, S. N., Hwang, W-J., Imamura, Y. (2005): Preliminary evaluation of new quarternary ammonia compound didecyl dimetyl ammonium tetrafluoroborate for preventing fungal decay and termite attack. The International Research Group on Wood Protection, (Bangalore - India), IRG/WP 05-30375, 9 p.

Kartal, S. N., Brischke, C., Rapp, A. O., Imamura, Y. (2006): Biocidal resistance of didecyl dimetyl ammonium tetrafluoroborate (DBF)-treated wood in soil-bed and 
Basidiomycetes tests. The International Research Group on Wood Protection, (Tromso Norway), IRG/WP 06-30393, 9 p.

Kazemi, S. M., Hosinzadeh, A., Rezaii, M. B. (2006): The effect of woody and non woody plants extractives on microbial resistance of non-durable species. The International Research Group on Wood Protection, (Tromso - Norway), IRG/WP 06-30392, 10 p.

Kirkpatrick, J. W., Barnes, H. M. (2006): Biocide treatments for wood composites - a review. The International Research Group on Wood Protection, (Tromso - Norway), IRG/WP 06-40323, 21 p.

Kizlink, J., Fargašová, A., Reinprecht, L. (1996a): Evolutional organotin compounds for biocidal wood protection:- suitable for small tonnage production. Drevársky výskum, 41(2): 19-29.

Kizlink, J., Fargašová, A., Reinprecht, L. (1996b): Comparison of the effectiveness of various organotin compounds with 2-thiocyanomethylthiobenzothiazoles as anti-fungal and anti-mould wood preservatives. Biologia, 51(6): 671-675.

Kizlink, J., Popelka, D., Švajlenová, O., Reinprecht, L. (2003): Med'naté cheláty Nsalicylidénaminokyselín pre chemickú ochranu dreva proti drevokazným hubám /Copper chelates N-salyciledene-aminoacids for chemical protection of wood against wood-destroying fungi/. Chem. Listy, 97(8): 672-673.

Krajewski, K. J., Strzelczyk-Urbaňska, A. A. (2009): European biocidal products market after implementation of Directive 98/8/EC - Report from the Commission to the Council and the European Parliament. Annals of Warszaw University of Life Sciences Forestry and Wood Technology, 67: 156-167.

Leithoff, H., Blancquaert, P. (2006): The future of wood protection in the light of the BPD Biocidal Products Directive 98/8/EC of 16.02.1998. Cost Action E37 - Sustainability through New Technologies for Enhanced Wood Durability, 8th May 2006, Poznaň Poland.

Lekounougou, S., Ondo, J. P., Jacquot J. P., Nevers, G., Gérardin, P., Gelhaye, E. (2007): Effects of caffeine on growth of wood-decaying fungi. The International Research Group on Wood Protection, (Wyoming - USA), IRG/WP 07-30427, 9 p.

Lin, L., Furuno, T. (2001): Biological resistance of wood-metaborate composites using the borax solution system. The International Research Group on Wood Preservation, (Nara Japan), IRG/WP 01-30259, 24 p.

Lloyd, J. D., Dickinson, D. J., Murphy, R. J. (1990): The probable mechanism of action of boric acid and borates as wood preservatives. The International Research Group on Wood Preservation, IRG/WP 1450.

Lloyd, J. D. (1998): Borates and their biological application. The International Research Group on Wood Protection, (Maastricht - Nederland), IRG/WP 98-30178, 24 p.

Lloyd, J. D., Fogel, J. L., Vizel, A. (2001): The use of zirconium as an inert fixative for borates in preservation. The International Research Group on Wood Preservation, (Nara Japan), IRG/WP 01-30256, 26 p.

Luo, J., Chen, H., Morrell, J. J. (2005): Effect of borate on uptake and efficacy of an antisapstain treatment. The International Research Group on Wood Protection, (Bangalore India), IRG/WP 05-30380, 11 p. 
Lyon, F., Thevénon, M-F., Pizzi, A., Gril, J. (2009): Resistance to decay fungi of ammonium borate oleate treated wood. The International Research Group on Wood Protection, (Beijing - China), IRG/WP 09-30505, 10 p.

Maoz, M., Morrell, J. J. (2004): Ability of chitosans to limit wood decay under laboratory conditions. The International Research Group on Wood Preservation, (Ljubljana Slovenia), IRG/WP 04-30339, 10 p.

Maoz, M., Weitz, I., Blumenfeld, M., Freitag, C., Morrell, J. J. (2007): Antifungal activity of plant derived extracts against G. trabeum. The International Research Group on Wood Protection, (Wyoming - USA), IRG/WP 07-30433, 13 p.

Mazela, B., Bartkowiak, M., Ratajczak, I. (2007): Animal protein impact on fungicidal properties of treatment formulations. Wood Research, 52(1): 13-22

Matsunaga, H., Kiguchi, M., Evans, P. (2007): Micro-distribution of metals in wood treated with a nano-copper wood preservative. The International Research Group on Wood Protection, (Wyoming - USA), IRG/WP 07-40360, 10 p.

McIntyre, C. R. (2010): Comparison of micronized copper particle sizes. The International Research Group on Wood Protection, (Biarritz - France), IRG/WP 30538, 12 p.

Messner, K., Facker, K., Lamaipis, P., Gindl, W., Srebotnik, E., Watanabe, T. (2003): Overview of white-rot research - where we are today. In: Wood deterioration and preservation. ACS Symp Ser 845, Am Chem Soc, Washington, DC, pp. 73-96.

Micales-Glaeser., Lloyd, J. D., Woods, T. L. (2004): Efficacy of didecyl dimethyl ammonium chloride (DDAC), disodium octaborate tetrahydrate (DOT), and chlorothalonil (CTL) against common mold fungi. The International Research Group on Wood Preservation, (Ljubljana - Slovenia), IRG/WP 04-30338, 14 p.

Milata, V., Claramunt, R. M., Cabildo, P., Santa, M. M. D., Cornago, P., Infantes, L., Cano, F. H., Elgure, J. (2001): 2,4,6-Tris(Azol-1-yl)-1,3,5-Triazines: A new Class of Multidentate Ligands. Heterocycles, 55(5): 905-924.

Milata, V., Reinprecht, L., Kizlink, J. (In press): Synthesis and antifungal efficacy of 1,3,5Triazines. Chem. Listy, (In press).

Mohareb, A., Badawy, M. E. I. (2008): Antifungal activity of different molecular weights of biopolymer chitosan against wood decay fungi. The International Research Group on Wood Protection, (Istanbul - Turkey), IRG/WP 08-30456, 10 p.

Mohareb, A., Thévenon M. F., Wozniak, E., Gérardin, P. (2010a): Effects of polyvinyl alcohol on leachability and efficacy of boron wood preservatives against decay and termites attack. The International Research Group on Wood Protection, (Biarritz France), IRG/WP 10-30526, 9 p.

Mohareb, A., Sirmah, P., Desharnais, L., Dumarcay, S., Pétrissans, M., Gérardin P. (2010b): Influence of extractives on durability of Cupressus lusitanica heartwood. The International Research Group on Wood Protection, (Biarritz - France), IRG/WP 1010716, $12 \mathrm{p}$.

Nicholas, D. D., Preston, A. F. (1980): Evaluation of alkyl ammonium compounds as potential wood preservatives. Proc. Am. Wood Pres. Assoc., 76: 13-21.

Nicholas, D. D., Williams, A. D., Preston, A. F., Zhang, S. (1991): Distribution and permanency of DDAC in southern pine sapwood treated by the full-cell process. Forest Products Journal, 41(1): 41-45. 
Pallaske, M. (2004): Chemical wood protection: Improvement of biocides in use. COST Action E22 - Environmental Optimisation of Wood Protection, 22-23.3.2004, Lisboa Portugal, $11 \mathrm{p}$.

Pankras, S., Cooper, P., Ung, T., Awoyemi, L. (2009): Copper to quat ratio in alkaline copper quat (ACQ) wood preservative: Effects on fixation and leaching of preservative components. The International Research Group on Wood Protection, (Beijing - China), IRG/WP 09-30496, $12 \mathrm{p}$.

Peek, R-D., Willeitner, H. (1984): Beschleunigte fixierung chromathaltiger holzschulzmittel durch heißdampfbehandlung. Holz als Roh- und Werkstoff, 42: 241-244.

Phillips-Laing, E. M., Staines, H. J., Palfreyman, J. W. (2003): The isolation of specific biocontrol agents for the dry rot fungus Serpula lacrymans. Holzforschung, 57: 574-578.

Pizzi, A., Baecker, A. W. (1996): A new boron fixation mechanism for non-toxic wood preservatives. Holzforschung, 50(6): 507-510.

Preston, A. F. (2000): Wood preservation - Trends of today that will influence the way tomorrow. Forest Products Journal, 50(9): 12-19.

Ray, M., Dickinson, D. J., Archer, K. (2010): A comparison of the performance of related copper based preservatives against soft rot. The International Research Group on Wood Protection, (Biarritz - France), IRG/WP 10-30540, 16 p.

Reinprecht, L., Mahút, J., Osvald, A. (1986): K problematike vplyvu ochranných látok na odolnost' preglejok voči plesniam /Study about the preservatives efficacy on the plywood resistance against moulds/. Drevo, 41(10): 301-303.

Reinprecht, L., Štefka,V. (1989): Drevotrieskové dosky pojené močovinoformaldehydovým a fenolformaldehydovým lepidlom s prídavkom fungicídov / Particleboards bonded with urea-formaldehyde and phenol-formaldehyde adhesives with addition of fungicides/. In: Pokroky vo výrobe a použití lepidiel v drevopriemysle, 9th Symposium, Chemko Strážske - Czechoslovakia, pp. 227-238.

Reinprecht, L. (1992): Strength of deteriorated wood in relation to its structure. Monograph VPA/2/92, Technical University in Zvolen - Czechoslovakia, 76 p.

Reinprecht, L., Perlác, J. (1995): Properties of particleboards protected by TBTN and TCMTB fungicides. In: Wood Modification '95, 10th Symposium, Poznaň - Poland, pp. 255264.

Reinprecht, L. (1996): TCMTB and organotin fungicides for wood preservation - efficacy, ageing, and applicability. Monograph - VŠ/A/10/96, Technical University in Zvolen Slovakia, 65 p.

Reinprecht, L., Kizlink, J. (1996): Efficiency of organotin dithiocarbamate derivatives against wood destroying fungi. Acta Facultatis Xylologiae TU Zvolen 1996/II., XXXVIII: 7587.

Reinprecht, L., Kizlink, J. (1999): Synthesis and anti-fungal screening test of organotin dithiocarbamates. Drevársky výskum, 44(3-4): 67-74.

Reinprecht, L., Kizlink, J., Švajlenová, O. (2003): Fungicídna účinnost' karbaminátov a med'natých chelátov /Fungicidal efficacy of carbamates and copper complexes/. Acta Fac. Rer. Nat. Univ. Ostr. Biol. Ekol., 210(9): 29-34.

Reinprecht, L. (2007): Selected laboratory tests of boron efficacy against wood-damaging fungi. ProLigno, 3(3): 27-37. 
Reinprecht, L., Kizlink, J. (2007): Wood preservatives prepared from electrical and cooling wastes. Acta Facultatis Ecologiae TU Zvolen, 15: 71-76.

Reinprecht, L., Pánek, M. (2007): Fungicídna účinnost' bóru v prostriedku na ochranu dreva s podielom amónnych solí /Fungicide efficacy of boron in the wood preservative containing ammonium salts/. Acta Facultatis Xylologiae TU Zvolen, XLIX(2): 53-62.

Reinprecht, L., Tiralová, Z. (2007a): Biocídy na ochranu dreva - aplikácia v interiéroch /Biocides for wood preservation - application in interiors/. Stavebné materiály, 3(6): 52-54.

Reinprecht, L., Tiralová, Z. (2007b): Biocídy na ochranu dreva - aplikácia v exteriéroch /Biocides for wood preservation - application in exteriors/. Stavebné materiály, 3(78): 45-48.

Reinprecht, L. (2008): Ochrana dreva Wood protection/. Handbook, Technical University in Zvolen - Slovakia, $453 \mathrm{p}$.

Reinprecht, L., Vidholdová, Z. (2008): Termodrevo - príprava, vlastnosti a aplikácie /Thermowood - its preparation, properties and application/. Monograph, Technical University in Zvolen - Slovakia, 89 p.

Reinprecht, L., Kohútová, M. Reinprecht, M. (2009): Fungicídny účinok N-salicylidénglutamáto-med'natých komplexov proti drevokazným hubám Coniophora puteana a Trametes versicolor/Fungicide efficacy of N-salicylidene-glutamato-copper(II) complexes against the wood-destroying fungi Coniophora puteana and Trametes versicolor/. In: Drevoznehodnocujuce huby 09, 6 ${ }^{\text {th }}$ Symposium about the Wooddegrading Fungi, TU Zvolen - Slovakia, pp. 57-64

Richardson, B. A. (1993): Wood preservation. E \& FN SPON, London.

Schiling, S. J., Inda, J. J. (2010): Toward an assessment of copper bioavailability in treated wood. The International Research Group on Wood Protection, (Biarritz - France), IRG/WP 10-20445, $10 \mathrm{p}$.

Schmidt, O. (2006): Wood and tree fungi - Biology, damage, protection, and use. Springer Verlag, Berlin Heidelberg, $334 \mathrm{p}$.

Schmidt, O., Müller, J., Moreth, U. (1995): Potentielle schutzwirkung von Chitosan gegen holzpilze. Holz-Zentralblatt, 121: 2503.

Singh, T., Chittenden C. (2008): In-vitro antifungal activity of chill extracts in combination with Lactobacillus casei against common sapstain fungi. International Biodeterioration and Biodegradation, 62:364-367.

Singh, T., Singh, A, P. (2010): Natural compounds: a rewiew of their use for wood protection. The International Research Group on Wood Protection, (Biarritz - France), IRG/WP 10-30545, 22 p.

Slovak standards: STN 490604

Stirling, R., Morris, P. I. (2010): Degradation of carbon-based preservatives by black-stain fungi. The International Research Group on Wood Protection, (Biarritz - France), IRG/WP 10-30533, 9 p.

Suttie, E. (2008): Sustainability benefits of wood protection. In: Cost Action E37 Sustainability through New Technologies for Enhanced Wood Durability, Final Conference in Bordeaux - France, pp. 5-11.

Švajlenová, O., Plesch, G., Mlynarčík, D. (1997): Vlastnosti a antimikróbna aktivita diazol(N-salicylidén-alanináto)med'natých komplexov /Properties and antimicrobial 
activity of diazole-(N-salyciledene-alaninato/copper complexes/. Chem. Listy, 91: 640.

Tang, J. D., Sonstegard, T., Burgess, S., Diehl, S. V. (2010): A genomic sequencing approach to study wood decay and copper tolerance in the brown rot fungus Antrodia radiculosa. The International Research Group on Wood Protection, (Biarritz - France), IRG/WP 10-10720, $14 \mathrm{p}$.

Taylor, A. M., Gartner, B. L., Morrell, J. J. (2002): Heartwood formation and natural durability - a review. Wood and Fiber Science, 34(4): 587-611.

Thevenon, M. F., Pizzi, A. (2003): Polyborate ions influence on the durability of wood treated with non-toxic protein borate preservatives. Holz als Roh- und Werkstoff, 61: 457-464.

Unger, A., Schniewind, A. P., Unger, W. (2001): Conservation of wood artefacts. SpringerVerlag Berlin Heidelberg, 578 p.

Van Acker, J., Stevens, M., Carey, J., Sierra-Alvarez, R., Militz, H., Le Bayon, I., Kleist, G., Peek, R-D. (2003): Biological durability of wood in relation to end-use - Part 1. Towards a European standard for laboratory testing of the biological durability of wood. Holz als Roh- und Werkstoff, 61: 35-45.

Viitanen, H., Ritschkoff, A-C. (1991): Mould growth in pine and spruce sapwood in relation to air humidity and temperature. Swed Univ Agric Sci Dept Forest Prod, Uppsala Sweden, Report No. 221.

Wang, J., Morris, P. I. (2010): A review on conditions for decay initiation and progression. The International Research Group on Wood Protection, (Biarritz - France), IRG/WP 1020444, 10 p.

Wallace, D. F., Dickinson, D. J. (2006): The bacterial transformation of organic biocides: a common mechanism? The International Research Group on Wood Protection, (Tromso Norway), IRG/WP 06-10585, 7 p.

Watkinson, S., Tlalka, M. (2008): Limiting fungal spread in buidings without the use of toxic biocides. In: Cost Action E37 - Sustainability through New Technologies for Enhanced Wood Durability, Final Conference in Bordeaux - France, pp. 41-46.

Wažny, J., Kundzewicz, A. (2008): Conditions and possibility of nanobiocides formulation for wood protection. The International Research Group on Wood Protection, (Istanbul Turkey), IRG/WP 08-30467, 9 p.

Wilcox, W. W. (1978): Review of literature on the effects of early stages of decay on wood strength. Wood and Fiber, 9(4): 252-257.

Woo, Ch. S., Morris, P. I. (2010): Sensitivity of copper of basidiospores from copper tolerant fungi Fomitopsis pulastris and Oligoporus placentus. The International Research Group on Wood Protection, (Biarritz - France), IRG/WP 10-10707, 9 p.

Wüstenhöfer, B., Wegen, H-W., Metzner, W. (1993): Triazole - eine neue fungizidgeneration für holzschutzmittel. Holz-Zentralbaltt, 119(58): 984 and 988.

Xie, Y., Krause, A., Mai, C., Militz, H., Richter, K., Urban, K., Evans, P. D. (2005): Weathering of wood modified with the N-methylol compound 1,3-dimethylol-4,5dihydroxyethyleneurea. Polymer Degradation and Stability, 89: 189-199.

Xue, W., Kennepohl, P., Ruddick, J. N. R. (2010): A comparison of the chemistry of alkaline copper and micronized copper treated wood. The International Research Group on Wood Protection, (Biarritz - France), IRG/WP 10-30528, 10 p. 
Zabel, R. A., Morrell, J. J. (1992): Wood microbiology - decay and its prevention. Academic Press, Inc. Harcourt Brace Jovanovich, Publishers.

Zabielska-Matejuk, B., Skrzypczak, A. (2006): Ionic liquids with organic and inorganic anions as highly active wood preservatives. The International Research Group on Wood Protection, (Tromso - Norway), IRG/WP 06-30411, 8 p. 


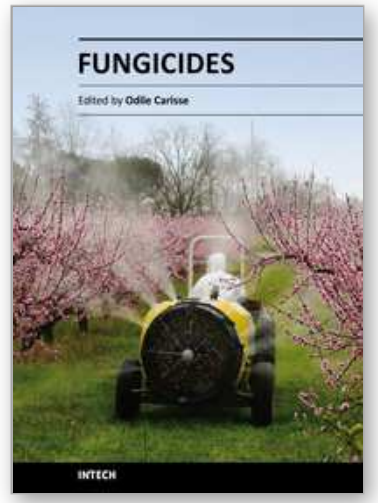

\author{
Fungicides \\ Edited by Odile Carisse
}

ISBN 978-953-307-266-1

Hard cover, 538 pages

Publisher InTech

Published online 14, December, 2010

Published in print edition December, 2010

Plant and plant products are affected by a large number of plant pathogens among which fungal pathogens. These diseases play a major role in the current deficit of food supply worldwide. Various control strategies were developed to reduce the negative effects of diseases on food, fiber, and forest crops products. For the past fifty years fungicides have played a major role in the increased productivity of several crops in most parts of the world. Although fungicide treatments are a key component of disease management, the emergence of resistance, their introduction into the environment and their toxic effect on human, animal, non-target microorganisms and beneficial organisms has become an important factor in limiting the durability of fungicide effectiveness and usefulness. This book contains 25 chapters on various aspects of fungicide science from efficacy to resistance, toxicology and development of new fungicides that provides a comprehensive and authoritative account for the role of fungicides in modern agriculture.

\title{
How to reference
}

In order to correctly reference this scholarly work, feel free to copy and paste the following:

Ladislav Reinprecht (2010). Fungicides for Wood Protection - World Viewpoint and Evaluation/Testing in Slovakia, Fungicides, Odile Carisse (Ed.), ISBN: 978-953-307-266-1, InTech, Available from: http://www.intechopen.com/books/fungicides/fungicides-for-wood-protection-world-viewpoint-and-evaluationtesting-in-slovakia

\section{INTECH}

open science | open minds

\section{InTech Europe}

University Campus STeP Ri

Slavka Krautzeka 83/A

51000 Rijeka, Croatia

Phone: +385 (51) 770447

Fax: +385 (51) 686166

www.intechopen.com

\section{InTech China}

Unit 405, Office Block, Hotel Equatorial Shanghai No.65, Yan An Road (West), Shanghai, 200040, China 中国上海市延安西路65号上海国际贵都大饭店办公楼405单元 Phone: +86-21-62489820

Fax: $+86-21-62489821$ 
(C) 2010 The Author(s). Licensee IntechOpen. This chapter is distributed under the terms of the Creative Commons Attribution-NonCommercialShareAlike-3.0 License, which permits use, distribution and reproduction for non-commercial purposes, provided the original is properly cited and derivative works building on this content are distributed under the same license. 